\title{
True Polar Wander driven by late-stage volcanism and the distribution of paleopolar deposits on Mars
}

\section{Citation}

Kite, Edwin S., Isamu Matsuyama, Michael Manga, J. Taylor Perron, and Jerry X. Mitrovica. 2009. "True Polar Wander Driven by Late-Stage Volcanism and the Distribution of Paleopolar Deposits on Mars." Earth and Planetary Science Letters 280 (1-4): 254-67. https://doi.org/10.1016/ j.epsl.2009.01.040.

\section{Permanent link}

http://nrs.harvard.edu/urn-3:HUL.InstRepos:41401435

\section{Terms of Use}

This article was downloaded from Harvard University's DASH repository, and is made available under the terms and conditions applicable to Other Posted Material, as set forth at http:// nrs.harvard.edu/urn-3:HUL.InstRepos:dash.current.terms-of-use\#LAA

\section{Share Your Story}

The Harvard community has made this article openly available. Please share how this access benefits you. Submit a story.

Accessibility 


\section{True polar wander driven by late-stage volcanism and the}

\section{2 distribution of paleopolar deposits on Mars}

4 Edwin S. Kite ${ }^{1}$, Isamu Matsuyama ${ }^{1,2}$, Michael Manga ${ }^{1}$, J. Taylor Perron $^{3}$, Jerry X. Mitrovica ${ }^{4}$

6 1. Earth and Planetary Science, 307 McCone Hall \#4767, University of California, Berkeley, CA 94720

7 USA (kite@berkeley.edu)

8 2. Department of Terrestrial Magnetism, Carnegie Institution of Washington, Washington, DC.

9 3. Earth, Atmospheric and Planetary Sciences, MIT, 77 Massachusetts Ave., Cambridge, MA.

10 4. Department of Physics, University of Toronto, 60 St. George Street, Toronto, Ontario, Canada.

12 Abstract.

13 The areal centroids of the youngest polar deposits on Mars are offset from those of adjacent paleopolar

14 deposits by $5-10^{\circ}$. We test the hypothesis that the offset is the result of true polar wander (TPW), the

15 motion of the solid surface with respect to the spin axis, caused by a mass redistribution within or on

16 the surface of Mars. In particular, we consider the possibility that TPW is driven by late-stage

17 volcanism during the late Hesperian to Amazonian. There is observational and qualitative support for

18 this hypothesis: in both North and South, observed offsets lie close to a great circle $90^{\circ}$ from Tharsis, as

19 expected for polar wander after Tharsis formed. We calculate the magnitude and direction of TPW

20 produced by mapped late-stage lavas for a range of lithospheric thicknesses, lava thicknesses, eruption

21 histories, and prior polar wander events. We find that if Tharsis formed close to the equator, the

22 stabilizing effect of a fossil rotational bulge located close to the equator leads to predicted TPW of $<2^{\circ}$, 
23 too small to account for observed offsets. If, however, Tharsis formed far from the equator, late-stage

24 TPW driven by low-latitude, late-stage volcanism would be $6-33^{\circ}$, similar to that inferred from the

25 location of paleopolar deposits. A mass of $4.4 \pm 1.3 \times 10^{19} \mathrm{~kg}$ of young erupted lava can account for the

26 offset of the Dorsa Argentea Formation from the present-day south rotation pole. This mass is

27 consistent with prior mapping-based estimates and would imply a mass release of $\mathrm{CO}_{2}$ by volcanic

28 degassing similar to that in the atmosphere at the present time. The South Polar Layered Deposits are

29 offset from the present rotation pole in a direction that is opposite to the other paleopolar deposits. This

30 can be explained by either a sequential eruption of late-stage lavas, or an additional contribution from a

31 plume beneath Elysium. We predict that significant volcanic activity occurred during the time interval

32 represented by the Basal Unit/Planum Boreum unconformity; Planum Boreum postdates the Promethei

33 Lingula Lobe; and that the north polar deposits span a substantial fraction of Solar System history. If

34 the additional contribution to TPW from plumes is small, then we would also predict that Tharsis

35 Montes formation postdates the the Promethei Lingula Lobe of the South Polar Layered Deposits. We

36 conclude with a list of observational tests of the TPW hypothesis.

38 Keywords. Mars; true polar wander; Hesperian; Amazonian; volcanism; ice-sheets

\section{1. Introduction.}

41 Paleopolar deposits in the polar regions of Mars are not centered on the present spin axis. Although

42 obliquity changes are probably responsible for the waxing and waning of ice-rich deposits in the

43 Martian low latitudes (Forget et al., 2006) and mid-latitudes (Head et al., 2006), it has proved

44 problematic to account for these near-polar offsets using obliquity change. Moderate increases in mean

45 obliquity (to $\sim 35^{\circ}$ from the present $\sim 25^{\circ}$ ) extend the latitudinal range over which water ice is stable, but

46 this expansion should be approximately symmetric about the pole - in contrast with the grossly 
asymmetric distribution of the paleopolar deposits. At still higher obliquity $\left(\geq 40^{\circ}\right)$, all Mars General

48 Circulation Models (GCMs) predict fast loss of polar water to form a low-latitude ice necklace

49 (Mischna et al., 2003).

Topographic control of atmospheric circulation and ice mass balance has been proposed as an

51 explanation for the offset of some present-day polar deposits. The low topography of the Hellas and

52 Argyre impact basins forces a planetary wave which accounts for the offset of the carbon-dioxide

53 Southern Residual Cap (SRC) from the present-day spin axis (Colaprete et al., 2005). The thickest part

54 of the southern polar layered plateau underlies the SRC, consistent with topographic control of long-

55 term water-ice deposition as well. However, Hellas and Argyre are both Noachian (> 3.6 Ga), and the

56 only significant topographic changes in the Southern Hemisphere since the mid-Hesperian $(\sim 3.4 \mathrm{Ga})$,

57 in the Tharsis and Syria provinces, could have little effect on either the magnitude or direction of

58 topographically-controlled asymmetry (Colaprete et al., 2005). In addition, we see a larger pattern

59 involving offset of both the north and south polar deposits that suggests that the location of the water

60 ice caps and associated ancient deposits are not due to asymmetric atmospheric effects.

We now turn to the alternative hypothesis of late-stage true polar wander, first proposed for the

62 Martian polar deposits by Murray \& Malin (1973). True Polar Wander (TPW) is the movement of a

63 planet's entire lithosphere with respect to the spin axis in response to changes in mass distribution. Here

64 we apply TPW theory (Gold, 1955; Goldreich \& Toomre, 1969; Willeman, 1984; Matsuyama et al.,

65 2006) to assess whether relatively recent volcanism in the Martian low- and mid-latitudes could be

66 responsible, through surface-load driven TPW, for shifts in the distribution of Mars' polar ice sheets

67 since $\sim 3.5 \mathrm{Ga}$. Because most Martian volcanic and tectonic activity predates $\sim 3.5$ Gya, we refer to this

68 as "late-stage" TPW.

69

The basic idea is shown in Figure 1. Lavas postdating the older polar deposits on Mars, but

70 predating younger polar deposits, change the geoid and so can shift the spin axis and the location of ice 
71 accumulation. Late-stage TPW on Mars is a long-standing hypothesis (Murray \& Malin, 1973; Schultz

72 \& Lutz, 1988; Tanaka, 2000; Fishbaugh \& Head, 2000), but both TPW theory, and Martian geological

73 and geodetic data, have been refined in recent years and so permit a quantitative analysis. Both surface

74 and internal loads can drive TPW, but young volcanic loads are more amenable to testing as a possible

75 driving load because their size and location are relatively well constrained. Our intent is to test if these

76 geologically plausible loads can produce the required TPW to explain the polar deposit offsets.

True Polar Wander of modest magnitude $\left(\leq 10^{\circ}\right)$ has been previously suggested to be responsible

78 for the distribution of both north (Murray \& Malin, 1973; Fishbaugh and Head, 2001) and south

79 (Tanaka, 2000) polar materials. Because the oldest polar materials are Early Amazonian in the north

80 and Late Hesperian in the south, late-stage TPW requires loading the lithosphere in the Late Hesperian

81 or Amazonian. By this time the bulk of the Tharsis load, which dominates the Martian geoid, was

82 already in place (Phillips et al., 2001). However, volcanism has persisted throughout the Amazonian,

83 resurfacing much of the Tharsis and Elysium regions - 15\% of the planet's surface, of which some

84 four-fifths lies north of the present-day equator (Nimmo and Tanaka, 2005). The areal centroid of these

85 lavas is $21 \mathrm{~N} 215 \mathrm{E}$; without other loads they would have driven the pole north along the $215 \mathrm{E}$ line. This

86 is approximately the direction of offset between polar and paleopolar deposits in the north - an

87 observation that motivates our more detailed study.

Here we evaluate the conditions under which TPW driven by recent surface loading may

89 account for the offset between past and present polar caps. Our scenario complements, but does not

90 require, proposed TPW events of greater $\left(\geq 30^{\circ}\right)$ magnitude and age that have been invoked to solve

91 geological puzzles earlier in Martian history (e.g. Perron et al., 2007).

92

93 2. The geologic record of polar ice sheets

94 The residual ice caps at the Martian poles (Herkenhoff et al., 2006) are underlain and abutted by 
materials that have been mapped as the eroded remnant of past ice-sheet deposits (Figure 2). In the north, relatively young polar layered deposits (Planum Boreum units of Tanaka et al., 2008), compositionally dominated by water ice and $\sim 1500$ m thick, are underlain by older, more lithic-rich materials (the Basal Unit of Fishbaugh and Head, 2005, platy unit of Byrne and Murray, 2002, lower unit of Edgett et al., 2003, Rupes Tenuis and Planum Boreum cavi units of Tanaka et al., 2008; we use the first term), comprising $\leq 1400 \mathrm{~m}$ of interbedded layers of sand and fractured ice. Radar sounding (Phillips et al., 2008) has confirmed the indication from geological mapping (e.g. Fishbaugh \& Head, 2005) that the center of these older, more lithic-rich materials is offset from the center of Planum Boreum by $\sim 300 \mathrm{~km}\left(\sim 5^{\circ}\right)$ along $180 \mathrm{E}$ (Figure 2$)$. Near 180E, these sand-rich materials embay and overlie the Scandia terrain, which bears large rimmed depressions interpreted as dead-ice topography (Fishbaugh and Head, 2000). To generate these features would require thick $(>100 \mathrm{~m})$ and extensive $(>$ $\left.5 \times 10^{4} \mathrm{~km}^{2}\right)$ 'ice sheets', by contrast with the thin $(\leq 10 \mathrm{~m})$ midlatitude icy layers associated with the recent high-obliquity ice ages (Head et al., 2003). It is unclear how far Scandia morphologies extend beneath the Basal Unit. If they mark the perimeter of a past ice sheet of similar radius to that of the Planum Boreum plateau, then its center was offset from the center of Planum Boreum by $\sim 450 \mathrm{~km}$ (an additional $\sim 150 \mathrm{~km}$ ) along the $200 \mathrm{E}$ line. All of the above units are superposed on the interior Vastitas Borealis plain, which has an earliest Amazonian crater-retention age by definition (Tanaka, 2005). Still larger offsets are inferred in the south. The $\mathrm{CO}_{2}$-dominated Southern Residual Cap is offset by $2.7^{\circ}$ from the present-day spin axis, and the distribution of the underlying, water-ice Planum Australe plateau is very asymmetric. A lobe, wedge-shaped in cross-section (Plaut et al., 2007b), extends in the $180 \mathrm{E}$ direction, so that the plateau's areal centroid is at $\sim 85 \mathrm{~S}$, although its volumetric centroid is closer to the pole (Figure 2). Stratigraphic correlation shows that this lobe represents a subset of Planum Australe's history (the Promethei Lingula Layer sequence of Milkovich \& Plaut, 2008). Older and younger sequences within Planum Australe are only found poleward of 80N; this may 
119 reflect their original extent, or asymmetric aeolian erosion (e.g., Koutnik et al., 2005). Limning Planum

120 Australe between longitudes $240 \mathrm{E}$ and 105E, and most extensive near $300 \mathrm{E}$ and near 10E, is a region

121 of sinuous, braided ridges and smooth plains punctured by sharp-rimmed depressions, which is mapped

122 as the Dorsa Argentea Formation (DAF) (Fig. 6b). Radar shows an ice-rich layer extending to 600-

$123900 \mathrm{~m}$ depth in this area (Plaut et al., 2007a), supporting the subglacial-melting hypothesis for the DAF

124 (Head and Pratt, 2001), which has a Hesperian crater-retention age. Radar shows kilometer-deep

125 depressions beneath Planum Australe resembling the Cavi Angusti within the DAF (Plaut et al., 2007b),

126 so the DAF likely continues beneath the polar plateau. This interpretation, indicating a paleo-cap offset

127 by $\sim 10^{\circ}(\sim 600 \mathrm{~km})$ from the spin axis along the $335 \mathrm{E}$ line, is also supported by the pattern of outcrop.

128

\section{3. Reorientation of Mars by surface loading}

130 A rotating fluid planet in hydrostatic equilibrium, subject to a superimposed nonequatorial surface load, 131 reorients to place that mass excess on the equator. However, if a planet has a lithosphere with elastic 132 strength at spherical harmonic degree two, the equilibrium location of the surface load is not at the 133 equator, but at an intermediate latitude less than that of loading (Willemann, 1984; Ojakangas and

134 Stevenson, 1989; Matsuyama et al., 2006, 2007).

135 On Mars, late-stage TPW is also affected by 1) the strong tendency of the preexisting Tharsis

136 load to remain near the equator (Perron et al., 2007) (all plausible young loads are much smaller than

137 Tharsis), and 2) the unknown orientation of a fossil equatorial bulge, a "frozen-in" relic of the planet's

138 spin orientation prior to Tharsis emplacement (Willemann, 1984). Geoid constraints favor solutions

139 with Tharsis forming close to the equator - in which case the bulge would also lie close to the present-

140 day equator - but still permit Tharsis to have formed far from the equator, in which case the bulge

141 would lie at a high angle to today's equator (Daradich et al., 2008). We treat both configurations.

142 We follow Matsuyama et al. (2006) to calculate the inertia tensor perturbations and the 
143 corresponding pole position by diagonalizing the inertia tensor. First, we consider the perturbations

144 associated with the young loads, Tharsis, and the remnant bulge to find the spin-axis orientation prior

145 to the formation of Tharsis and the young loads. Then, given this initial spin-axis orientation, we

146 consider the perturbations associated with Tharsis and the remnant bulge alone to calculate the spin-

147 axis orientation after the formation of Tharsis (Table 1a). We use a standard value for the size of the

148 geoid perturbation due to the Tharsis load (from Willemann, 1984), although the true value may be

149 greater or smaller.

150 In practice, Martian volcanism is episodic (Wilson et al., 2001). The viscous relaxation time of Mars

151 determines whether TPW would also have been episodic, or smoothed. We simplify by considering the

152 equilibrium response of the planet to a single loading event - equivalent to assuming that the viscous

153 relaxation time is much shorter than the interval separating younger from older polar deposits.

\section{4. Calculation of TPW due to young volcanic loads}

156 We focus on igneous loads emplaced on top of the elastic lithosphere ("surface volcanic loads") - we 157 justify this in §6.3). Using geological unit boundaries slightly modified from digitally renovated global 158 maps (Skinner et al., 2006; Scott and Tanaka, 1986; Greeley and Guest, 1987), we assess the total

159 thickness of young volcanic materials (lavas, plus relatively shallow intrusions) for each unit (Figure 3;

160 Table S1).

161 Some units are smooth plains, others are edifices (lobes and cones). We assume uniform

162 thicknesses for plains lavas, since sub-plains topography is rarely known. Our values resemble those of

163 Greeley and Schneid (1991). For edifices, we either assume uniform thickness (a late-stage drape over

164 a Noachian-Early Hesperian core), or truncate near the base (assuming that the majority of the edifice

165 is late-stage). Planar truncation does not account for the volume of the filled-in flexural pit beneath the 166 edifice, so the truncated volume underestimates the total edifice volume. There is disagreement over 
167 the volume-averaged age of volcanoes that have very young surface ages. For example, Dohm et al.

168 (2001) reconstruct Olympus Mons as forming in the Late Hesperian/Amazonian, but Werner (2005)

169 favors formation of Olympus in the Noachian/Early Hesperian. Elastic thickness estimates entail

170 geothermal gradients generally consistent with late formation (McGovern et al., 2004). However, the

171 extent to which these estimates are quantitatively reliable is unclear (Belleguic et al., 2005), especially

172 if volcanoes form above hotspots. To span this uncertainty, we assign 'small', 'medium' and 'large'

173 thicknesses to each unit (Figure 3; Table S1). We also model TPW driven by drapes of uniform

174 thickness within the boundary of Late Hesperian/Amazonian volcanic materials given by Nimmo and

175 Tanaka (2005).

176 [New age estimates and volumes became available as this paper was in revision. Using crater-

177 counts on High-Resolution Stereo Camera (HRSC) images, Werner (in press) infer that the bulk of the

178 Tharsis Montes, Olympus Mons, and Elysium were emplaced before the Late Hesperian, although

179 flank volcanism, caldera activity, and extrusion of flood lavas continued through to the Late

180 Amazonian. These results suggest that Late Hesperian/Amazonian volcanism can be approximated as a

181 uniform drape of $100 \mathrm{~m}$ to perhaps a few hundred meters thickness, similar to Figure 3a.]

182 Load density $\rho$ is set to $3 \times 10^{3} \mathrm{~kg} \mathrm{~m}^{-3}$. This is conservative for the largest volcanoes (Belleguic et

183 al., 2005), but overestimates the density of the Medusae Fossae Formation $\left(\rho \leq 1.9 \times 10^{3} \mathrm{~kg} \mathrm{~m}^{-3}\right.$;

184 Watters et al., 2007). This error is small compared to the range in thickness estimates. Only that portion

185 of the load that is uncompensated will drive TPW. For each load, we self-consistently calculate flexure

186 using fluid Love numbers, and obtain the total geoid perturbation due to the load.

187 We model late-stage TPW for a range of elastic thicknesses $\left(\mathrm{T}_{\mathrm{e}}\right)$, for both the cases where

188 Tharsis formed close to and far from the equator (Table 1a). Because, once formed, Tharsis must

189 remain near the equator, the direction of TPW is always close to $160 \mathrm{E}$ ( $90^{\circ}$ from the center of Tharsis).

190 For fixed $\mathrm{T}_{e}$, the magnitude of TPW is approximately linear in load volume for reasonably-sized loads. 
191 However, it is much greater for the case where Tharsis forms far from the equator than where Tharsis

192 forms close to the equator; even with the 'large' load, we obtain no more than $1.6^{\circ}$ of TPW in the latter

193 case. This is because the configuration with the fossil rotational bulge at a small inclination to the

194 present-day equatorial plane is very stable (Perron et al., 2007). For fixed load volume, the extent of

195 late-stage TPW increases with increasing $\mathrm{T}_{\mathrm{e}}$, because the level of load compensation decreases; this

196 effect dominates the increasing magnitude of the remnant rotational bulge, which acts to resist TPW.

197 Results for drapes of uniform thickness behaved similarly, implying that it is the magnitude of young

198 volcanism, rather than its exact distribution, that is more important in determining the TPW response.

199 For simplicity, we assume that the same $\mathrm{T}_{\mathrm{e}}$ characterizes the remnant rotational bulge and the young

200 volcanic loads.

201 To illustrate the relationship between volcano position and TPW response, we also calculated

202 the response to the 'large' estimates of volume for individual volcanic provinces (Table 1b). Polar offset

203 vectors so calculated cannot be meaningfully added, because the TPW response is non-linear.

204 Apart from Alba Patera, whose effect is to increase the Tharsis load and move Tharsis slightly closer to

205 the equator, most paleopoles lie along the great circle $90^{\circ}$ from Tharsis (Figure 5). The sense of the

206 shift induced by these volcanic provinces can be understood by inspection of Figure 4. The Medusae

207 Fossae Formation and Tharsis Montes provinces have volumetric centroids S of the center of Tharsis in

208 the west-of-Tharsis hemisphere, giving polar shifts in the opposite sense to that of the most voluminous

209 provinces, which lie $\mathrm{N}$ of the equator in the west-of-Tharsis hemisphere. Among these voluminous

210 provinces, TPW magnitude is strongly dependent on load longitude (Matsuyama et al., 2006). Elysium

211 is only slightly more massive than Olympus Mons, but because its longitude is close to $90^{\circ}$ from

212 Tharsis it drives a shift $\sim 3$ times greater than Olympus Mons.

213 Stratigraphic correlations between Elysium and Tharsis are imprecise, although widespread

214 volcanism on the Elysium rise must have concluded during the Early Amazonian (Tanaka et al., 1992). 
215 The consensus among stratigraphers is that overlapping periods of activity occurred at Mars' main late-

216 stage volcanic centers, rather than sequential eruption at one province followed by another. For all

217 these reasons, a good starting point when discussing polar wander paths is to assume that the activities

218 of the Tharsis and Elysium volcanic centers were proportional. However, as will be discussed in $\S 5$, our

219 TPW results illuminate the stratigraphic relations between volcanism and polar activity, allowing us to

220 reconstruct an alternative 'sequential' history (provided that TPW is in fact responsible for the observed

221 offsets). This sequence corresponds to the timing of near-surface emplacement of the bulk of the

222 volume of the volcanoes, not to emplacement of the youngest crater-bearing surfaces.

223

\section{5. Comparison with paleopoles inferred from geology}

\section{5.1. Geologically inferred paleopoles}

226 Areas of past water ice concentration have been inferred using geology (Tanaka, 2005), and neutron227 spectrometer maps of upper-metre $\mathrm{H}$ abundance (Dohm et al., 2007). Although the second dataset may 228 contain valuable information about ancient ( $>5$ Mya) ice sheets, the possibility that $\mathrm{H}$ is present in

229 salts rather than ice (Basilevsky et al., 2006), and overprinting by recent ( $\leq 5$ Mya) atmosphere-regolith

230 exchange (Jakosky et al., 2005), complicates interpretation of these shallow materials. We define

231 paleopolar deposits using topographic and digitized geological data only (Figure 6): Tanaka and Scott

232 (1987) for the south; Tanaka et al. (2005) for the north. The Scandia formation is mapped (Tanaka et

233 al., 2005) as being much more extensive than the area of large, rimmed depressions (Scandia Cavi).

234 Rather than use the entire Scandia formation to define a paleopole, we use Mars Orbiter Laser

235 Altimeter (MOLA) topography to draw the margins of the Scandia depressions and eskers. A zone of

236 unusual, large moated domes (Scandia Tholi) encircles the Scandia depressions. These may have been

237 built up by the extrusion of shallow slurries (Tanaka et al., 2003), and slurry extrusion could occur

238 without differential loading from an advancing or retreating ice sheet (Kite et al., 2007). But the domes 
239 have also been suggested to represent kame-and-kettle topography (Fishbaugh \& Head, 2000), so we 240 use MOLA topography to define their convex hull as a possible paleopolar deposit. We define a single 241 paleopole using the Olympia dome, which is the only extensive area where the Basal Unit probably lies 242 close to the surface. This involves the assumption that the part of the Basal Unit making up the bulk of 243 the Olympia dome is conformable on, or contemporaneous with, the part of the Basal Unit that forms 244 the base of Planum Boreum (Fishbaugh \& Head, 2005); however, Tanaka et al. (2008) argue that the 245 first part is separated from the second by a major unconformity.

246 Polar caps are centered close to the spin axis today (average deviation $2.4^{\circ}$, Table 2 ), and are 247 likely to have tracked the spin axis in the past, at least during conditions of low $\left(<40^{\circ}\right)$ obliquity. We 248 show the distance between young polar caps and the present-day spin axis in Figure 6, by dashed lines 249 bracketing the calculated polar wander track. This is our estimate of the 'proxy error' involved in using 250 polar caps as proxies for the location of the spin axis. Radar indicates that the Basal Unit continues 251 under much of Planum Boreum (Putzig et al., 2008), and the spatial distribution of Dorsa Argentea 252 Formation outcrop strongly suggests that it continues under the thickest part of Planum Australe. 253 Therefore, the areal centroid of present-day outcrop of a paleopolar deposit cannot be considered a 254 paleopole. Instead, we approximate past ice sheets by circles, and define a simple penalty function to 255 evaluate the goodness of fit of a given circular planform to geological boundaries. Incorrect inclusion 256 of non-paleopolar material and exclusion of paleopolar material both score +1 per grid cell $\left(\sim 9 \mathrm{~km}^{2}\right)$, 257 and correct inclusion of paleopolar material is rewarded with a score of -1 per cell. Overlying materials 258 are masked out and not scored. We then define the paleopole for a given geological unit to be the center 259 of the circular ice-sheet with the minimum score, searching systematically over cap latitude and 260 longitude. The circle that best fits Olympia Planum matches the area of Basal Unit independently 261 mapped by radar (Putzig et al., 2008), lending credence to our assumption that paleopolar caps were 262 approximately circular. We do not attempt a formal error estimate for the paleocenter locations: this 
263

264

265

266

267

268

269

270

271

272

273

274

275

276

277

278

279

280

281

282

283

284

285 286 deposits.

would have to take into account incomplete geological preservation, mapping imprecision, non-circular ice sheets, and possible asymmetric retreat. We consider that these effects introduce an error in assigning a centroid location to a paleopolar deposit comparable to the 'proxy error' defined above. This additional 'measurement error' is shown by the outer green circles in Figure 6.

In the north, we only consider past ice-sheets with radii equal to that of present-day Planum Boreum (Greenwood et al., 2008). We find best-fitting pole locations for the Olympia dome, for the Scandia depressions, and for the Scandia depressions and mounds taken together (Table 1a). Ice outliers, large areas of perennially high albedo south of the Olympia dome, bracket the polar wander path associated with progressive emplacement of a volcanic load (§4; Figure 6a). They have only superficial topographic expression, and their age is uncertain. They may be recent deposits unrelated to the Scandia depressions, in which case it would be inappropriate to fit them. Alternatively, if they are outliers of a formerly more extensive polar plateau (Zuber et al., 1998), then they should be weighted when defining paleopoles. We plot only the first possibility, which we consider more likely because the ice outliers superpose most other deposits (Table 1a; Figure 6) and are still annually frosting and defrosting (Calvin and Titus, 2008). The calculated polar wander path including the ice outliers (not shown) runs along $180( \pm 10) \mathrm{E}$.

Taken together, our paleopoles in the north define a polar wander path of magnitude $(5 \pm 2)^{\circ}$ (Figure 6a). This increases to $(7 \pm 2)^{\circ}$ if the enigmatic Scandia mounds also indicate ice-sheet processes. The Basal Unit paleopole is almost as close to the spin axis as is the upper part of Planum Boreum, so TPW is only one of several possible explanations for the offset of the Basal Unit from the spin axis and from the center of the upper part of Planum Boreum. For example, pre-existing (and now-buried) topography could have seeded growth of an ice-sheet. Subsequently, the Basal Unit topographic rise might have shifted atmospheric circulation to favor off-center deposition of younger volatile-rich 
In the south, caps with radius equal to that of Planum Australe cannot give a good fit to the

288 location of the DAF. When we allow the paleo-ice-sheet radius to increase, we obtain a much more 289 satisfactory fit. This may be because the Martian surface lost water between DAF time and Scandia

290 time (Kulikov et al., 2007), so that the DAF ice-sheet was more voluminous. In addition, higher

291 lithospheric heat flux (Solomon et al., 2005) may have permitted the ice-sheet to flow downslope,

292 leading to a noncircular planform and greater width:height ratio. Geological syntheses based on image

293 interpretation (Ghatan \& Head, 2004) suggest that the DAF ice-sheet was at least locally hydrologically

294 active, indicating a bed temperature near the pressure melting point. This would have permitted much

295 more rapid ice creep than within the present-day polar layered deposits (Goldsby \& Kohlstedt, 2001).

296 Bedrock topography in the south polar region favors asymmetric accumulation and flow: it is more

297 rugged, and has steeper long-baseline tilts, than the north polar region (Plaut et al., 2007b). The best-

298 fitting ice sheet, with radius $1020 \mathrm{~km}$ (q.v. $700 \mathrm{~km}$ for Planum Australe), is centered along our

299 calculated TPW path. Its offset relative to the present-day spin axis is $7.9^{\circ}$, and we use this value in the

300 Discussion. However, given the importance of Southern Hemisphere topography in controlling

301 precipitation patterns near the south pole, it is arguably better to measure the offset relative to the SRC

$302\left(5.2^{\circ}\right)$. In this case, the volume of volcanism needed to generate TPW is reduced by $1 / 3$, but our

303 conclusions are not qualitatively affected.

304

$305 \quad 5.2$ Assessment of the late-stage TPW hypothesis

306 In Figure 6 we compare paleopole locations inferred from geological constraints (Table 1a) to those

307 computed using loading theory (Table 1a). As episodic volcanism progressively emplaced the young

308 volcanic load, the magnitude of TPW would have increased. Therefore older paleopolar deposits should

309 show progressively larger offsets from the present-day spin axis, a prediction that matches observations

310 (Figure 6) and correlations between north and south (Figure 7). 
If Tharsis formed close to the equator, volcanically-driven TPW can explain at most the location

312 of the Basal Unit, even with the 'large' estimated volcanic load. Accounting for the older deposits

313 requires instead that Tharsis formed far from the equator. In that case, even the 'small' load gives TPW

314 sufficient to explain the offset between the present-day spin axis and the DAF.

315 The trend of the paleopoles in the north clearly deviates from the great circle $90^{\circ}$ from Tharsis

316 (Figure 6a). However, Paleopoles $1-2$ (which lie close to the great circle $90^{\circ}$ from Tharsis) are more

317 reliable than Paleopole 3 (which does not) because of the greater area of outcrop of the Planum Boreum

318 and the Basal Unit compared to that of the Scandia depressions. Fitting caps to relatively small

319 outcrops introduces additional uncertainty into the pole calculation. In turn, Paleopoles 1-3 are much

320 more reliable than Paleopole 4 (the biggest outlier), because we do not know what created the Scandia

321 Tholi. Moreover, the ice outliers, which are thickest in the $110 \mathrm{E}-180 \mathrm{E}$ sector, might mute topographic

322 evidence for ice-sheet action to the west of our paleopoles, introducing an eastward bias in paleopole

323 longitude. Therefore, we consider the distribution of paleopolar deposits in the north polar region

324 consistent with TPW, although certainly not compelling when considered in isolation.

325 In the south, all geologically-inferred paleopoles lie along our calculated polar wander path

326 (Figure 6b). As expected given its greater age, the DAF shows a larger offset from the present-day spin

327 axis than does the Basal Unit. The center of Planum Australe lies along our calculated TPW path, but in

328 the opposite direction from that expected for proportional emplacement of young volcanic loads $(\S 5.3)$.

329 Given the plausibility of our input parameters, and the acceptable match between observed and

330 calculated polar wander magnitudes and directions, we favor the late-stage TPW explanation for the

331 distribution of paleopolar deposits on Mars. However, if later research confirms that Tharsis in fact

332 formed close to the equator, this will rule out TPW driven by surface loads as an explanation for the

333 distribution - unless late-stage Martian magmatism was much more voluminous than in current models.

334 Gravity data to degree and order 2 are better fit by a small-TPW scenario than by a large-TPW scenario 
335 (Daradich et al., 2008), but that work did not consider loads other than Tharsis and the fossil rotational

336 bulge (such as internal loads, or the late-stage surface loads considered in this paper). More detailed

337 modeling of gravity anomalies and geodynamic history might help to constrain the latitude at which

338 Tharsis formed.

\subsection{Example integrated volcanic and polar history of Late Hesperian/Amazonian Mars}

341 Because Tharsis dictates the path of late-stage TPW, our inferred TPW path cannot be used to infer the 342 exact location of its causative loads (Figure 4). For example, the difference in polar wander direction

343 for TPW driven by Elysium versus Olympus is negligible, despite the $>70^{\circ}$ of longitude separating

344 Elysium and Olympus. The longitude resolution of our geologically inferred paleopoles is also poor, so

345 we cannot constrain load longitude much better than by quadrant (Figure 4). However, in combination

346 with upper limits on load volume from MOLA topography, and lower limits on unit age from crater

347 counts, we identify a possible sequence of volcanic loading episodes and pole shifts, and polar

348 deposition episodes (Figure 7).

349 The sequence starts with deposition of the Dorsa Argentea Formation in the Late Hesperian. The 350 Elysium rise is already partly in place (Figure 7a). Waning Elysium activity, increasingly supplemented 351 by proto-Olympus Mons, drives the pole $\sim 5.5^{\circ}$ towards $335 \mathrm{E}$ (towards the hemisphere centered on the 352 Martian meridian) during Scandia and prior to Basal Unit time (Figure 7b). The top of the Basal Unit 353 marks a major unconformity in the north. Olympus Mons and Arcadia flood lavas move the pole a 354 further $\sim 8.1^{\circ}$ meridian-ward, $\sim 5.7^{\circ}$ beyond its present location. The Promethei Lingula Lobe of the

355 South Polar Layered Deposits forms after this loading event (Figure 7c). Next, the locus of volcanism

356 shifts east to the Tharsis Montes, reversing the sign of TPW and bringing the spin axis to its present 357 configuration. Thicker lithosphere allows a given load to produce a greater geoid anomaly, so cooling 358 of the planet enhances TPW during this final stage. Planum Boreum is deposited during this TPW 
event, $\mathrm{a} \sim 5.7^{\circ}$ shift in the anti-meridian direction (Figure $7 \mathrm{~d}$ ), accounting for its offset from the present-

360 day north rotation pole (Figure 6a). The Medusae Fossae Formation, Syria and Alba play subsidiary

361 roles (Figure 5).

362 This sequence of events assumes there has been little change in the contribution to the geoid

363 from internal loads and dynamic topography over the past $\sim 3.5$ Gyr. In $\S 6.3$, we relax this assumption,

364 and suggest that construction of the Elysium province, followed by cessation of plume activity beneath

365 Elysium, is an alternative and perhaps simpler explanation of the observations. If late-stage volcanism

366 at the Tharsis Montes has been volumetrically minor (Werner, in press), late-stage Tharsis Montes

367 volcanism would have been insufficient to generate the $\sim 5.7^{\circ}$ shift in the anti-meridian direction shown

368 in Figure 7d, and a contribution from internal loads would be required to explain this step of Mars'

369 inferred TPW history.

370

371 6. Discussion

\section{6.1. Implications for rates of melting and degassing}

$373 \mathrm{~T}_{\mathrm{e}}$ is probably $\geq 300 \mathrm{~km}$ today (Phillips et al., 2008), but was $93 \pm 40 \mathrm{~km}$ at the time of Olympus Mons

374 emplacement (Belleguic et al., 2005). Given the decay of the mantle's radiogenic heat source, the

375 relevant $T_{e}$ is probably close to $\sim 100 \mathrm{~km}$, the value for the Early Amazonian when most of the load

376 would have been emplaced.

377 Given the linear relationship between load volume and magnitude of TPW (Table 1a) for

378 geologically defensible loads, we can use geologically inferred TPW to estimate the subsequent volume

379 of volcanism (Figure 8). For example, taking the Dorsa Argentea Formation to be $\sim 3.6$ Ga old

380 (Hartmann, 2005), the average rate of volcanism since is $(4.1 \pm 1.2) \times 10^{-3} \mathrm{~km}^{3} \mathrm{yr}^{-1}$. This is less than the

381 pre-MOLA estimate of Greeley and Schneid (1991), $7.3-14.6 \times 10^{-3} \mathrm{~km}^{3} \mathrm{yr}^{-1}$, but matches thermal

382 evolution models (O'Neill et al., 2007). 
384 large uncertainties (Hirschmann and Withers, 2008) - we can estimate total late-stage volatile release to 385 the atmosphere. For the case where Tharsis forms far from the equator, and $\mathrm{T}_{\mathrm{e}}=100 \mathrm{~km},(4.4 \pm 1.3) \times 10^{19}$

$386 \mathrm{~kg}$ magma (which, if completely degassed, would have released $5.8 \pm 1.8 \mathrm{mbar} \mathrm{CO}_{2}$ ) should have been 387 extruded since DAF time, and (2.8 \pm 1.3$) \times 10^{19} \mathrm{~kg}$ magma (which, if completely degassed, would have 388 released 3.6 \pm 1.7 mbar $\mathrm{CO}_{2}$ ) since the Scandia depressions formed. This falls to $3.3 \pm 1.0 \mathrm{mbar}$ and $3892.1 \pm 1.0$ mbar respectively if with $T_{e}=200 \mathrm{~km}$. Quoted errors consider only the error in paleopole 390 positions, not in $T_{e}$. Our best-estimate of total late stage degassing, $\sim 6$ mbar, is also the size of the 391 present-day near-surface $\mathrm{CO}_{2}$ reservoir (6.4 mbar in the atmosphere, and 0.4 mbar in the SRC). Present-day Martian atmospheric pressure reflects the balance of Late Hesperian/Amazonian

393 volcanic degassing and atmospheric loss, added to whatever atmosphere was inherited from 'early

394 Mars'. The inherited atmosphere would have been very tenuous if the active young Sun drove $\mathrm{CO}_{2}$ loss 395 rates greatly in excess of volcanic degassing rates during the Noachian/Early Hesperian (Manning et al., 2006). In that case, the rough equivalence of TPW-derived volcanic degassing estimates and present-day atmospheric pressure would require that atmospheric loss rates were smaller than volcanic

398 degassing rates, integrated over the Late Hesperian/Amazonian. In other words, long-term average 399 atmospheric mass and globally-averaged surface temperature may have been increasing over the last 400 three-quarters of Martian history, with important implications for geomorphology and the likelihood of 401 surface liquid water (see also Richardson \& Mischna, 2005). The requirement that atmospheric loss 402 rates be small is consistent with the paucity of carbonates on the Martian surface (Bibring et al., 2006), 403 and with Mars Express measurements of present-day atmospheric escape rates - which are equivalent 404 to only $0.2-4$ mbar $\mathrm{CO}_{2}$ extrapolated over $3.5 \mathrm{Ga}$ (although not all processes have been quantified) 405 (Barabash et al., 2007). 


\subsection{Are Planum Boreum and Planum Australe old enough to have experienced TPW?}

408 Our proposed TPW scenario implies an age for Planum Australe and the upper part of Planum Boreum 409 that is older than some estimated ages, but consistent with others. If they formed recently (e.g., $<5 \mathrm{Myr}$

410 in the North; Phillips et al., 2008), geologically detectable TPW is unlikely to have occurred since.

411 TPW acts to filter out high temporal frequencies, and the only non-polar changes in surface load since

4125 Mya have been the emplacement of thin (Campbell et al., 2007) lavas, perhaps the uppermost

413 member of the Medusae Fossae Formation (Watters et al., 2007), and perhaps partial sublimation of

414 non-polar icy deposits (Head et al., 2006). Collectively, these load changes could have produced only

415 minor TPW. However, estimating the age of icy deposits is difficult, because sublimation of overburden

416 may remove craters, and crater topography possibly undergoes viscous relaxation. The largest craters,

417 though few in number, imply a surface age of $>330$ Myr for the upper part of Planum Boreum, and

$418>500$ Myr for Planum Australe (Pathare et al., 2005). Because the stratigraphy of the north polar

419 layered deposits cannot yet be definitively linked with a known time scale (Perron and Huybers, 2009),

420 it remains possible that the upper part of Planum Boreum is significantly older than a few million years.

421 Therefore, either or both Planum Australe and the upper part of Planum Boreum may be old enough to

422 have undergone geologically measurable TPW, which may help to explain the offset of their areal

423 centers from the present-day spin axis.

425 6.3. Other loads

426 If mantle plumes underlie Tharsis and Elysium, they may have changed intensity (O'Neill et al., 2007)

427 or position over time. However, the geoid anomaly at degree 2 (the wavelength relevant to TPW)

428 produced by a plume of constant flux and position changes little as the lithosphere thickens over time

429 (Roberts and Zhong, 2004). Rouby et al. (2008) show that plume initiation could have led to $1-15^{\circ}$ of

430 TPW on pre-Tharsis Mars, setting aside stabilization by the fossil rotational bulge. 
432 The decline of volcanic activity may correspond to a waning of plume activity beneath Elysium. If so,

433 then the 'overshoot and rebound' relative to today's spin-axis recorded by the locations of the polar

434 deposits could be due solely to Elysium. Our reasoning is as follows. On Mars, the geoid anomaly due

435 to mantle plumes at wavelengths appropriate for Elysium is probably positive (upwards), though small

436 (Roberts and Zhong, 2004); the positive anomaly due to dynamic topography supported by the rising

437 mantle exceeds the negative anomaly due to the low-density mantle forming the plume. Therefore, with

438 plume-supported volcanism, the combination of a dynamic, internal load and a growing surface load

439 induces greater TPW than the surface load alone. This could correspond to the evolution from a) to c)

440 in Figure 7 (the 'overshoot'). Removal of the internal load, for example by a waning plume, is in effect

441 a negative load. This could correspond to the evolution from c) to d) in Figure 7 (the 'rebound').

442 Polar wander driven by dust, ice, or material deposited by the waning circum-Chryse outflows

443 was probably small compared to the volcanically-driven wander assessed here. The thin Vastitas

444 Borealis outflow channel deposits certainly predate the Scandia terrain, and probably largely predate

445 the Dorsa Argentea Formation. The TPW contribution of the ice sheets themselves would have been

446 minor unless vastly more ice was available for atmospheric transport in the past than at present.

447 On Earth, basalt underplating the low-density crust during plume impingement may match or

448 exceed erupted volumes (Cox, 1995). Such 'bottom loading' on Mars would complicate our analysis.

449 We cannot distinguish between true polar wander of the lithosphere-plus-mantle relative to the

450 spin axis, and differential motion of the lithosphere with respect to the mantle. Our calculations in $\S 3$

451 assume the former. The alternative has recently been proposed (Zhong, 2009), and would lead to very

452 different implications for Martian volcanic (and climatic?) history. 
455 We have established the plausibility of geologically significant late-stage TPW on Mars, but our

456 conclusions depend on assumptions about the volcanic and polar history of Mars that need to be tested.

457 The TPW hypothesis would be disfavored if analysis of crater size-frequency distributions showed a

458 Noachian/Early Hesperian density of buried craters at shallow depths throughout the area of young

459 volcanism. Provided that the intrusive:extrusive volume ratio is comparable to terrestrial values $(\sim 5: 1$;

460 White et al., 2006), this could bound the volume of late-stage near-surface loads as less than required to

461 drive the proposed TPW. On the other hand, tectonic mapping might reveal patterns of fault

462 reactivation parsimoniously explained by lithospheric stresses due to late-stage TPW (Melosh, 1980).

463 Our best-fitting Scandia paleopoles imply that features similar to the Scandia rimmed depressions

464 extend under Planum Boreum about as far as the present-day spin axis. This predicts that the basal

465 interface of the Basal Unit should have hundreds of meters of relief at $10 \mathrm{~km}-100 \mathrm{~km}$ scales,

466 contrasting with the low $\sim 10 \mathrm{~km}$-scale roughness of the basal interface of Gemini Lingula (Phillips et

467 al., 2008) and of Vastitas Borealis (Kreslavsky \& Head, 2000). If radar shows these features to be

468 absent, asymmetric retreat of a formerly more extensive ice sheet (Fishbaugh \& Head, 2001) may be a

469 better explanation for the Scandia features.

470 Our late-stage TPW scenario alters the topographic boundary conditions for Noachian/Early

471 Hesperian climate by 1) removing volcanic edifices, and 2) shifting zonal climatic belts relative to the

472 lithosphere. Ventifacts at the mid-Hesperian Mars Pathfinder (MPF) landing site are oriented oblique to

473 the strongest present-day winds (Greeley et al., 2000); this cannot be accounted for by obliquity change

474 (Fenton \& Richardson, 2001; Haberle et al., 2003). If a GCM using the altered topographic boundary

475 conditions provided by our TPW scenario yields strong winds at the MPF site which parallel the

476 observed ventifacts, the hypothesis of late-stage TPW would be supported.

477 Also, if the significant offset between the centers of the Basal Unit and the upper NPLD is due

478 to TPW, the Basal Unit must predate a substantial fraction of Late Hesperian / Amazonian volcanism. 
479 Given that a recent surge in volcanism is unlikely (but not impossible), this entails a mid-Amazonian or

480 earlier Basal Unit age. Consequently, we predict that the north polar deposits span a substantial fraction

481 of Solar System history. If Martian polar stratigraphy records orbitally forced variations in insolation

482 (Montmessin, 2006), then the polar deposits of Mars might greatly extend the time range over which

483 geology constrains orbital dynamics (Olsen and Kent, 1999).

484

485 7. Conclusions

486 Late Hesperian/Early Amazonian paleopolar deposits near the Martian poles are offset from the

487 present-day poles in a manner inconsistent with simple obliquity change. We find that true polar

488 wander driven by late-stage, low-latitude volcanic loads can account for these observations, if (and

489 only if) Tharsis formed far from the equator. Gravity data favor scenarios where Tharsis forms close to

490 the equator, but permit scenarios where Tharsis forms far from the equator (Daradich et al., 2008).

Three of the four paleopolar deposits on Mars can be explained by proportional emplacement of

492 volcanic load, but the South Polar Layered Deposits cannot be explained in this way. The SPLD

493 paleopole can, however, be accounted for if the Tharsis Montes postdate the South Polar Layered

494 Deposits or if internal (plume-related) loads changed with time. By linking widely separated TPW-

495 inducing and pole-tracking deposits, TPW permits a new method of stratigraphic correlation that is

496 independent of crosscutting relationships and crater counts.

497 Our calculations illustrate (Fig. 7) that the locations of all of the paleopolar deposits near the

498 Martian poles could be the result of TPW, but our confidence level is high for only one of the four

499 deposits, the Dorsa Argentea Formation. Younger deposits are closer to the present-day spin axis, and it

500 is possible that meteorological factors are responsible for their offset from the pole. This could be

501 studied with a GCM of sufficient resolution $\left(\sim 1^{\circ}\right.$ in latitude).

502 The hypothesis of true polar wander driven by late-stage volcanism survives our test. 
Barabash, S., A. Federov, R. Lundin, and J.-E. Sauvaud (2007), Martian atmospheric erosion rates,

Science 315, 501-503.

Basilevsky, A.T., et al. (2006), Search for causes of the low epithermal neutron flux anomaly in the

Belleguic V., P. Lognonne, and M. Wieczorek (2005), Constraints on the Martian lithosphere from gravity and topography data, J. Geophys. Res. 110(E11), doi:10.1029/2005JE002437.

Bibring, J.-P., et al. (2006), Global Mineralogical and Aqueous Mars History Derived from OMEGA/Mars Express Data, Science 312, 400-404.

Bradley, B.A., S.E.H. Sakimoto, H. Frey, and J.R. Zimbelman (2002), Medusae Fossae Formation: New perspectives from Mars Global Surveyor, J. Geophys. Res. 107(E8), doi:10.1029/2001JE001537.

Byrne, S., and B.C. Murray (2002), North polar stratigraphy and the paleo-erg of Mars, J. Geophys. Res., 107(E6), 5044.

Calvin, W.M., and T.N. Titus (2008), Summer season variability of the north residual cap of Mars as observed by the Mars Global Surveyor Thermal Emission Spectrometer (MGS-TES), Planetary and Space Science, 56, 212-226.

Campbell, B.A., et al. (2007). SHARAD mapping of subsurface geological horizons in Amazonis Planitia. $7^{\text {th }}$ International conf. on Mars, abs. \#3225.

Colaprete, A., J.R. Barnes, R.M. Haberle, J.L. Hollingsworth, H.H. Kieffer, \& T.N. Titus (2005), Albedo of the south pole on Mars determined by topographic forcing of atmosphere dynamics, Nature 435, 184-188.

Cox, K.G. (1995), Continental magmatic undeplating, Phil. Trans. Roy. Soc. A., 342, 155-166.

Daradich, A., et al. (2008), Equilibrium rotational stability and figure of Mars, Icarus 194, 463-475.

Dohm, J.M., et al. (2001), Ancient drainage basin of the Tharsis region, Mars, J. Geophys. Res. 106(E12), 32,943-32,958.

Dohm, J.M., et al. (2007), Possible ancient giant basin and related water enrichment in the Arabia Terra province, Mars, Icarus 190, 74-92.

Edgett, K.S., R.M.E. Williams, M.C. Malin, B.A. Cantor, and P.C. Thomas (2003), Mars landscape evolution: influence of stratigraphy on geomorphology in the north polar region, Geomorphology 52, 289-297.

Fenton, L., and M.I. Richardson (2001), Martian surface winds: Insensitivity to orbital changes and implications for aeolian processes. J. Geophys. Res. 106(E12), 32,885-32,902. 
Fishbaugh, K.E. and J.W. Head (2000), North polar region of Mars: Topography of circumpolar deposits from Mars Orbiter Laser Altimeter (MOLA) data and evidence for asymmetric retreat of the

Fishbaugh, K.E., and J.W. Head (2001), Comparison of the north and south polar caps of Mars, Icarus 154, 145-161.

Fishbaugh, K.E., and J.W. Head (2005), Origin and characteristics of the Mars north polar Basal Unit and implications for polar geologic history, Icarus 174, 444-474.

Forget, F., R.M. Haberle, F. Montmessin, B. Levrard, \& J. W. Head (2006), Formation of glaciers on Mars by atmospheric precipitation at high obliquity, Science 311, 368-371.

Ghatan, G.J., and J.W. Head III (2004), Regional drainage of meltwater beneath a Hesperian-aged south circumpolar ice sheet on Mars, J. Geophys. Res. 109, doi:10.1029/2003JE002196.

Gold, T., (1955), Instability of the Earth's axis of rotation, Nature 175, 526- 529.

Goldreich, P., and A. Toomre (1969), Some remarks on polar wandering, J. Geophys. Res., 74, 25552567

Goldsby, D.L., and D.L. Kohlstedt (2001), Superplastic deformation of ice: Experimental observations, J. Geophys. Res. 106(B6), 11,017-11,030.

Greeley, R., and J.E. Guest (1986), Geological Map of the Western Equatorial Region of Mars, US Geol. Surv. Scientific Investigations I-1802-B

Greeley, R., and B.D. Schneid (1991), Magma generation on Mars: Amounts, rates, and comparisons with Earth, Moon and Venus, Science 254, 996-998.

Greeley, R., M.D. Kraft, R.O. Kuzmin, and N.T. Bridges (2000), Mars Pathfinder landing site: Evidence for a change in wind regime from lander and orbiter data, J. Geophys. Res. 105(E1), 18291840.

Greenwood, J.P., et al. (2008), Hydrogen isotope evidence for loss of water from Mars through time, Geophys. Res. Lett., doi:10.1029/2007GL032721, in press.

Haberle, R.M., J.R. Murphy and J. Schaeffer (2005), Orbital change experiments with a Mars general circulation model, Icarus 161(1), 66-89.

Hartmann, W.K., (2005), Martian cratering 8: Isochron refinement and the chronology of Mars, Icarus 174(2), 294-320.

Head, J.W., et al. (2003), Recent ice ages on Mars, Nature 426, 797-802.

Head, J.W., and S. Pratt (2001), Extensive Hesperian-aged south polar ice sheet on Mars: Evidence for 
massive melting and retreat, and lateral flow and pending of meltwater, J. Geophys. Res. 106(E5), 12275-12299.

Head, J.W., et al. (2006), Extensive valley glacier deposits in the northern mid-latitudes of Mars:

Evidence for Late Amazonian obliquity-driven climate change, Earth Planet. Sci. Lett. 241, 663-671.

Herkenhoff, K., S. Byrne, and K.L. Tanaka (2006), Mars polar geologic nomenclature: What are the caps? In: $4^{\text {th }}$ Mars Polar Sci. Conf. Abstract 8034.

Hirschmann, M.M., and A.C. Withers (2008), Ventilation of CO2 from a reduced mantle and consequences for the early Martian greenhouse, Earth and Planet. Sci. Lett. 270, 147-155.

Ivanov, M.A., and J.W. Head III (2006). Alba Patera, Mars: Topography, structure, and evolution of a unique late Hesperian-early Amazonian shield volcano, J. Geophys. Res., 111, E09003, doi:10.1029/2005JE002469.

Jakosky, B., M.T. Mellon, E.S. Varnes, W.C. Feldman, W.V. Boynton, and R.M. Haberle (2005), Mars low-latitude neutron distribution: Possible remnant near-surface water ice and a mechanism for its recent emplacement, Icarus 175, 58-67.

Kite, E.S., N. Hovius, J.K. Hillier, and J. Besserer (2007), Candidate mud volcanoes in the northern plains of Mars, American Geophysical Union, Fall Meeting 2007, abstract \#V13B-1346.

Koutnik, M.R., S. Byrne, B.C. Murray, A.D. Toigo, and Z.A. Crawford (2005), Eolian controlled modification of the martian south polar layered deposits, Icarus 174(2), 490-501.

Kreslavsky, M.A., and J.W. Head III (2000), Kilometer-scale roughness of Mars: results from MOLA data analysis. J. Geophys. Res. 105(E11), 26695-26711.

Kulikov, Y.N., et al. (2007), A comparative study of the influence of the active young sun on the early atmospheres of Earth, Venus, and Mars, Space Sci. Rev. 129, 207-243.

McGovern, P. J., et al. (2004), Correction to "Localized gravity/topography admittance and correlation spectra on Mars: Implications for regional and global evolution”, J. Geophys. Res., doi:10.1029/2004JE002286.

Manning, C.V., C.P. McKay, and K.J. Zahnle (2006), Thick and thin models of the evolution of carbon dioxide on Mars, Icarus 180, 38-59.

Matsuyama, I., et al. (2006), Rotational stability of dynamic planets with elastic lithospheres, Journal of Geophysical Research 111(E2), E02003.

Matsuyama, I., F. Nimmo, and J.X. Mitrovica (2007), Reorientation of planets with lithospheres: The effect of elastic energy, Icarus 191(2), 401-412.

Melosh, H.J. (1980), Tectonic patterns on a reoriented planet: Mars, Icarus 44, 745-751. 
643

644

645

646

647

648

649

650

651

652

653

654

655

656

657

658

659

660

661

662

663

664

665

666

667

668

669

670

671

672

673

674

675

676

677

678

679

680

681

682

683

684

685

686

687

688

689

Milkovich, S.M., and J.J. Plaut (2008), Martian South Polar Layered Deposit stratigraphy and implications for accumulation history, J. Geophys. Res., 113, E06007, doi:10.1029/2007JE002987.

Mischna, M.A., M.I. Richardson, R.J. Wilson and D.J. McCleese (2003), On the orbital forcing of martian water and $\mathrm{CO} 2$ cycles: A general circulation model study with simplified volatile schemes. J. Geophys. Res., 108(E6) 5062, doi:10.1029/2003JE002051.

Montmessin, F. (2006), The orbital forcing of climate changes on Mars, Space Sci. Rev. 125, 457-472.

Murray, B.C., and M.C. Malin (1973), Polar wandering on Mars?, Science 179, 997-1000.

Nimmo, F., and K.L. Tanaka (2005), Early crustal evolution of Mars, Annual Review of Earth and Planetary Sciences 33, 133-161.

Ojakangas, G.W., and D.J. Stevenson (1989), Polar wander of an ice shell on Europa, Icarus 81, $242-$ 270 .

Olsen, P.E., and D.V. Kent (1999), Long-period Milankovitch cycles from the Late Triassic and Early Jurassic of eastern North America and their implications for the calibration of the Early Mesozoic timescale and the long-term behaviour of the planets, Phil. Trans. Roy. Soc. A, 357, 1761-1786.

O'Neill, C., A. Lenardic, A.M. Jellinek, and W.S. Kiefer (2007), Melt propagation and volcanism in mantle convection simulations, with applications for Martian volcanic and atmospheric evolution, J. Geophys. Res. 112(E7), doi:10.1029/2006JE002799.

Pathare, A., D. A. Paige, and E. Turtle (2005), Viscous Relaxation of Craters within the Martian South Polar Layered Deposits, Icarus, 174, 396-418.

Perron, J.T., et al. (2007), Evidence of an ancient martian ocean in the topography of deformed shorelines. Nature, 447, 840-843.

Perron, J.T., and P. Huybers (2009), Is there an orbital signal in the polar layered deposits on Mars?, Geology, 37, 155-158, 10.1130/G25143A.1.

Phillips, R.J., et al. (2001), Ancient geodynamics and global-scale hydrology on Mars, Science 291, 2587-2591.

Phillips, R.J., et al. (2008), Mars North Polar Deposits: stratigraphy, age, and geodynamical response, Science 320, 1182-1185.

Plaut, J., et al. (2007a), Radar sounding of subsurface layers in the South Polar plains of Mars, LPSC $38,2144$.

Plaut, J., et al. (2007b), Subsurface Radar Sounding of the South Polar Layered Deposits of Mars, Science 316, 92-95.

Putzig, N.E., et al. (2008), Stratigraphic mapping of the north polar layered deposits on Mars from 
690

691

692

693

694

695

696

697

698

699

700

701

702

703

704

705

706

707

708

709

710

711

712

713

714

715

716

717

718

719

720

721

722

723

724

725

726

727

728

729

730

731

732

733

734

735

736

radar soundings, Lunar Planet Sci. Conf. 39, 2355.

Richardson, M.I., and M.A. Mischna (2005), Long-term evolution of transient liquid water on Mars, J.

Geophys. Res. 110, doi:10.1029/2004JE002367.

Roberts, J.H., and S. Zhong (2004), Plume-induced topography and geoid anomalies and their

implications for the Tharsis rise on Mars, J. Geophys. Res. 109, E03009, doi:10.1029/2003JE002226.

Rouby, H., Greff-Lefftz, M., and J. Besse (2008) Rotational bulge and one plume convection pattern:

Influence on Martian true polar wander, Earth and Planet. Sci. Lett. 272, 212-220.

Schultz, P., and A. Lutz (1988), Polar wandering of Mars, Icarus 73, 91-141.

Scott, D.H., and K.L. Tanaka (1986), Geological Map of the Western Equatorial Region of Mars, US

Geol. Surv. Scientific Investigations I-1802-A

Shean, D.E., Head, J.W., Fastook, J.L., and D.R. Marchant (2007), Recent glaciation at high elevations on Arsia Mons, Mars: Implications for the formation and evolution of large tropical mountain glaciers, J. Geophys. Res. 112, E03004, doi:10.1029/2006JE002671.

Skinner, J.A., T.M. Hare, and K.L. Tanaka (2006), Digital Renovation of the Atlas of Mars

1:15,000,000-Scale Global Geologic Series Maps, LPSC XXXVII, abstract \#2331.

Solomon, S., et al. (2005), New perspectives on ancient Mars, Science 307, 1214-1220.

Tanaka, K.L. (2000), Dust and ice deposition in the Martian geologic record, Icarus 144, 254-266.

Tanaka, K.L., and E.J. Kolb (2001), Geologic History of the Polar Regions of Mars Based on Mars Global Surveyor Data: I. Noachian and Hesperian Periods, Icarus 154(1), 3-21.

Tanaka, K.L., Chapman, M.G., and D.H. Scott (1992), Geologic map of the Elysium region of Mars, US Geol. Surv. Miscellaneous Investigations I-2147

Tanaka, K.L., J. A. Skinner Jr., T. M. Hare, T. Joyal, and A. Wenker (2003), Resurfacing history of the northern plains of Mars based on geologic mapping of Mars Global Surveyor data, J. Geophys. Res. 108, doi:10.1029/2002JE001908.

Tanaka, K.L., and D.H. Scott (1987), Geological Map of the Polar Regions of Mars, US Geol. Surv. Scientific Investigations I-1802-C

Tanaka, K.L., J.A. Skinner, and T.M. Hare (2005), Geologic Map of the Northern Plains of Mars, US Geol. Surv. Scientific Investigations I-2888 (http://pubs.usgs.gov/sim/2005/2888/).

Watters, T.R., et al. (2007), Radar sounding of the Medusae Fossae Formation Mars: Equatorial ice or dry, low-density deposits?, Science 318, 1125-1128.

Werner, S.C. (2005), Major aspects of the chronostratigraphy and geologic evolutionary history of 
741 White, S.M., J. Crisp, and F.J Spera (2006), Long-term volumetric eruption rates and magma budgets, 742 Geochem. Geophys. Geosyst. 7(3), doi:10.1029/2005GC001002.

744 Willeman, R. (1984), Reorientation of planets with elastic lithospheres: Icarus, vol. 60, pp. 701745709.

750 Zhong, S. (2009), Migration of Tharsis volcanism on Mars caused by differential rotation of the 751 lithosphere, Nature Geoscience 2, 19-23.

755 Zuber, M.T., et al. (1998), Observations of the North Polar Region of Mars from the Mars Orbiter Laser 756 Altimeter, Science 282, 2053-2060. 
757 Table 1. a) (Northern) paleopoles calculated for TPW driven by young volcanic load. Letters refer to

758 the solutions that are plotted on Figure 6. b) (Northern) paleopoles calculated for TPW driven by

759 individual volcanic provinces. See Figure 3a for province locations. Only 'large' loads considered. Far-

760 from-equator solutions are plotted on Figure 5.

761

762 Table 2. Best-fitting geologically inferred paleopole locations. OD = Olympia Dome; $\mathrm{PB}=\mathrm{Planum}$

763 Boreum, upper North Polar Layered Deposits (similar extent to that of residual water-ice cap); SC =

764 Scandia depressions; ST = Scandia mounds; IO = ice outliers; SRC = Southern Residual Cap $\left(\mathrm{CO}_{2}\right.$ ice $)$;

765 SPLD = South Polar Layered Deposits; DAF = Dorsa Argentea Formation. Deviation of youngest polar

766 deposits from spin axis $=(2.4 \pm 0.3)^{\circ}$. This uncertainty is one-sided for the SRC because atmospheric

767 effects forced by Noachian topography displace $\mathrm{CO}_{2}$ precipitation patterns meridian-ward. The final

768 column is a (subjective) confidence level that each paleopole is due to TPW. Requirements for a good

769 geologically inferred paleopole: Asymmetric retreat of formerly more extensive ice sheets is an

770 alternative explanation for the shape and distribution of Planum Boreum (Fishbaugh \& Head, 2001)

771 and Planum Australe. It is possible that asymmetric sublimation and aeolian erosion has affected the

772 shape of the Basal Unit plateau (Tanaka et al., 2008) and Planum Australe (Milkovich \& Plaut, 2008) to

773 the extent that their present-day areal centroids are not close to their past areal centroids. Present

774 outcrop distributions can only be useful as a guide to the past location of the spin axis if either: 1) the

775 ice-sheet is preserved largely intact; 2) original ice-sheet volume is decimated, but the areal extent of

776 the plateau is unaltered; 3) the ice sheet undergoes symmetric retreat; or 4) the ice sheet undergoes

777 asymmetric retreat, but leaves morphological signatures such as moraines, eskers, and kettles that allow

778 its original extent to be reconstructed. Asymmetric retreat of cold-based ice sheets (for which none of

779 these conditions need hold) could confound interpretation of the distribution of Martian paleopolar

780 deposits in terms of TPW. However, the original extent of cold-based high-obliquity ice sheets on the 
781 flanks of the Tharsis Montes has been reconstructed using moraines deposited during their incomplete 782 retreat (e.g., Shean et al., 2007).

783

784 Table S1. Load thicknesses. Unit designations are from I-1802AB. For each unit, we either assume a 785 uniform thickness (a relatively thin late-stage drape over Noachian-Early Hesperian materials), or 786 truncate the edifices near their base (which assumes that the bulk of the unit is Late Hesperian or

787 Amazonian). All units are meters (m). Uniform thicknesses are denoted by numbers without appended 788 parentheses. Parenthetical ' $\mathrm{T}$ ' denotes edifice truncated at this elevation, and thickness taken to be the 789 pixelwise $\left(1 / 4^{\circ} \times 1 / 4^{\circ}\right)$ thickness above that elevation. Negative thicknesses are not permitted. We 790 modified published geological maps by: 1) assigning $14^{\circ} \times 1 / 4^{\circ}$ areas shown on the map as either

791 'undivided', 'volcano, relative age unknown' or 'crater ejecta' to the nearest dated unit, 2) subdividing 792 members of the Tharsis Montes formation into Arsia Mons, Pavonis Mons and Ascreaus Mons sub793 members, and 3) following Bradley et al. (2002), subdividing the Medusae Fossae Formation by lobe 794 rather than by stratigraphic level

795

796 Figure 1. Azimuthal equal-area projection centered on 165E, 0N, showing relationship between load, 797 TPW response, and polar deposits. Grid spacing is $30^{\circ}$, in both latitude and longitude. Red tint is area 798 of Late Hesperian - Amazonian volcanics (Nimmo \& Tanaka, 2005), shown in more detail in Figure 3. 799 Blue and pink tones are polar and paleopolar deposits, shown in more detail in Figure 6. Yellow spot is 800 center of Tharsis load, at 248.3E, 6.7N (Zuber and Smith, 1997). Polar wander driven by post-Tharsis 801 loads of magnitude much smaller than Tharsis, the subject of this paper, lies close to the green line 802 (Tables 2 and 3), which is within $7^{\circ}$ of the great circle perpendicular to Tharsis. Positive loads in the $80368 \mathrm{E}-248 \mathrm{E}$ hemisphere $\mathrm{N}$ of the equator, or in the $248 \mathrm{E}-68 \mathrm{E}$ hemisphere $\mathrm{S}$ of the equator, will lever 804 the spin axis toward the top of the figure, relative to the lithosphere (Figure 4). Loads in the 68E - 
$805248 \mathrm{E}$ hemisphere $\mathrm{N}$ of the equator, or positive loads in the $248 \mathrm{E}-68 \mathrm{E}$ hemisphere $\mathrm{S}$ of the equator,

806 will lever the spin axis toward the base of the figure, relative to the lithosphere (Figure 4).

807

808 Figure 2. Sketch section showing a) south polar and b) north polar stratigraphy, drawn so that left is up

809 in Figure 1. Principal inferred direction of polar wander is from right to left. Line of section is the green

810 line in Figure 1; each section runs from 70S, through the pole, to 70S in the opposite hemisphere

811 ( 2400 km). Locally, the Dorsa Argentea Formation extends beyond 70N.

812

813 Figure 3. Close-up of region of volcanic loads. a) Uniform load with thickness 100m (total volume 3.0

$814 \times 10^{6} \mathrm{~km}^{3}$, of which $77 \%$ by volume lies $\mathrm{N}$ of equator). Labeled provinces are referred to in Table $1 \mathrm{a}$.;

815 b) 'Small' load (11.2 x $10^{6} \mathrm{~km}^{3}, 79 \%$ ); c) 'Medium' load (19.0 x $\left.10^{6} \mathrm{~km}^{3}, 77 \%\right)$, d) 'Large' load (35.4 x

$\left.81610^{6} \mathrm{~km}^{3}, 79 \%\right)$.

817

818 Figure 4. North polar projection showing dependence on latitude and longitude of TPW driven by a 819 small positive surface load. Vectors show the direction and magnitude of north pole displacement that

820 would be caused by placing the same load at different geographic locations within the northern

821 hemisphere. Concentric circles are $0 \mathrm{~N}, 30 \mathrm{~N}$, and $60 \mathrm{~N}$. Ratio of maximum TPW angles in plots is 1: 1.1

822 : 34.1. a) Without Tharsis, and with remnant rotational bulge at equator, the amount of TPW is small,

823 and any load displaces the pole along the line of longitude that passes through the load. b) Small

824 Tharsis-driven TPW scenario. The amount of TPW is still small, but in contrast to (a), the direction of

825 TPW generally has a component perpendicular to the meridian that passes through Tharsis. White

826 circle is pre-Tharsis pole; black circle is Tharsis location. c) Large Tharsis-driven TPW scenario. The

827 symbols for Tharsis and the pre-Tharsis pole overlap due to the map projection. TPW is large, but

828 restricted to directions perpendicular to the line of longitude that passes through Tharsis. 
830 Figure 5. South polar region showing province-by-province paleopoles (Table 1a). 'Large' load, large

831 TPW scenario. For each province, $T_{e}=100 \mathrm{~km}, 200 \mathrm{~km}$ and $300 \mathrm{~km}$ solutions are at increasing

832 distances from the pole. See Figure $6 \mathrm{~b}$ for key to polar geologic units.

833 There is some disagreement about the correct boundary of the Dorsa Argentea Formation. By

834 using the original boundary of Tanaka and Scott (1987), we adhere more closely to the preferred

835 boundary of Ghatan \& Head (2004) than to the revised boundary of Tanaka \& Kolb (2001).

836

837 Figure 6: a) North polar region, and b) South polar region, showing:- paleopoles computed from

838 estimates of young volcanic load (triangles; Table 1a for key); paleopoles inferred from geology

839 (nested green circles; Table 1a for key); and distribution of polar and paleopolar deposits (tinted areas).

840 Dark blue line is the convex hull of the Scandia mounds. Green dashed lines define error envelopes

841 based on the deviation of the youngest polar deposits from the current spin axis $\left(2.4 \pm 0.3^{\circ} \equiv 140 \pm 20\right.$

$842 \mathrm{~km}$, the 'proxy error' discussed in the text). We estimate that the additional error in assigning a centroid

843 locations to a paleopolar deposit ('measurement error') is comparable to or greater than this error, and

844 we show this additional error by the outer green circles. Ice outliers are probably young

845 (contemporaneous with upper Planum Boreum or younger), but are shown because they might be 846 obscuring older deposits.

848 Figure 7. One possible synthesis of Martian volcanic and polar history using TPW constraints and the 849 assumption that areal centroids of polar deposits track the spin axis. Degree of confidence increases 850 with observed offset. The contribution of internal dynamics to TPW is assumed to be small (see $\S 6.3$

851 for a discussion of this assumption). Other less simple syntheses are also consistent with the data.

852 Elevations are not to scale. a) Deposition of Dorsa Argentea Formation (DAF) during Hesperian. 
853 Ongoing volcanism at Elysium (Ely). b) Loading in Quadrants 1 or 3 (e.g. by Elysium or proto-

854 Olympus Mons, Oly; Figure 5) shifts pole by 5.9 degrees in great circle 90 deg from Tharsis in a 855 meridian-ward sense. Deposition of Scandia (Sc) materials intercalated with loading, Basal Unit (BU)

856 postdates loading. c) Further loading in Quadrants 1 or 3 (e.g. by waning Elysium flows, Olympus

857 Mons activity or Arcadia young flood lavas; Figure 5) drives further polar wander of 7.5 degrees in 858 meridian-ward sense. Deposition of Promethei Lingular Lobe of SPLD. d) Loading in Quadrants 2 or 4

859 (most likely by Tharsis Montes, TM; Figure 5) drives polar wander of 5 degrees in anti-meridian sense.

860 Deposition of Planum Boreum (PB) intercalated with or subsequent to loading. Deposition of the 861 geologically very young Southern Residual Cap (SRC).

862

863 Figure 8. Magnitude of TPW versus total volume of late Hesperian and Amazonian volcanism, for a 864 range of assumptions about lithospheric thickness and orientation of fossil rotational bulge. Colored 865 bars show range of magnitudes/volumes for which computed TPW matches geologically inferred 866 wander to within $\pm 1^{\circ}$. Red vertical lines are small, medium and large loads. The South Polar Layered 867 Deposits are not plotted because their offset cannot be accommodated by a 'proportional' volcanic 868 history. 


\begin{tabular}{|c|c|c|c|c|c|c|c|c|}
\hline \multicolumn{3}{|c|}{ a) Combined surface loads } & \multicolumn{3}{|c|}{ Tharsis formed close to equator } & \multicolumn{3}{|c|}{ Tharsis formed far from equator } \\
\hline Load & $\begin{array}{l}\text { Volu } \\
\text { me }(\mathrm{x} \\
10^{\wedge} 6 \\
\mathrm{~km}^{\wedge} 3 \\
)\end{array}$ & $\begin{array}{l}\text { Center of } \\
\text { volume }\end{array}$ & $\begin{array}{l}\mathrm{Te}= \\
100 \mathrm{~km}\end{array}$ & $\begin{array}{l}\mathrm{Te}= \\
200 \mathrm{~km}\end{array}$ & $\begin{array}{l}\mathrm{Te}= \\
300 \mathrm{~km} \text { (a) }\end{array}$ & $\begin{array}{l}\mathrm{Te}= \\
100 \mathrm{~km}(\mathrm{~b})\end{array}$ & $\begin{array}{l}\mathrm{Te}= \\
200 \mathrm{~km}(\mathrm{c})\end{array}$ & $\begin{array}{l}\mathrm{Te}=300 \mathrm{~km} \\
(\mathrm{~d})\end{array}$ \\
\hline $\begin{array}{l}\text { 'Small' } \\
\text { (A) }\end{array}$ & 11.2 & $\begin{array}{r}17.4 \mathrm{~N} \\
220.5 \mathrm{E} \\
\end{array}$ & $\begin{array}{r}89.8 \mathrm{~N} \\
181.7 \mathrm{E} \\
\end{array}$ & $\begin{array}{r}89.6 \mathrm{~N} \\
186.1 \mathrm{E} \\
\end{array}$ & $\begin{array}{r}89.5 \mathrm{~N} \\
185.2 \mathrm{E} \\
\end{array}$ & $\begin{array}{r}83.8 \mathrm{~N} \\
161.1 \mathrm{E} \\
\end{array}$ & $\begin{array}{r}79.3 \mathrm{~N} \\
162.3 \mathrm{E}\end{array}$ & $\begin{array}{r}77.3 \mathrm{~N} \\
163.0 \mathrm{E}\end{array}$ \\
\hline $\begin{array}{l}\text { 'Medium' } \\
\text { (B) }\end{array}$ & 19.0 & $\begin{array}{r}15.3 \mathrm{~N} \\
220.3 \mathrm{E}\end{array}$ & $\begin{array}{r}89.7 \mathrm{~N} \\
183.4 \mathrm{E}\end{array}$ & $\begin{array}{r}89.4 \mathrm{~N} \\
181.2 \mathrm{E}\end{array}$ & $\begin{array}{r}89.2 \mathrm{~N} \\
180.9 \mathrm{E}\end{array}$ & $\begin{array}{r}80.0 \mathrm{~N} \\
161.8 \mathrm{E}\end{array}$ & $\begin{array}{r}73.0 \mathrm{~N} \\
162.7 \mathrm{E}\end{array}$ & $\begin{array}{r}69.3 \mathrm{~N} \\
163.3 \mathrm{E}\end{array}$ \\
\hline $\begin{array}{l}\text { 'Large' } \\
\text { (C) }\end{array}$ & 35.4 & $\begin{array}{r}18.0 \mathrm{~N} \\
217.8 \mathrm{E}\end{array}$ & $\begin{array}{r}89.3 \mathrm{~N} \\
180.5 \mathrm{E}\end{array}$ & $\begin{array}{r}88.7 \mathrm{~N} \\
181.3 \mathrm{E}\end{array}$ & $\begin{array}{r}88.4 \mathrm{~N} \\
180.6 \mathrm{E}\end{array}$ & $\begin{array}{r}71.5 \mathrm{~N} \\
162.7 \mathrm{E}\end{array}$ & $\begin{array}{r}62.0 \mathrm{~N} \\
164.9 \mathrm{E}\end{array}$ & $\begin{array}{r}57.7 \mathrm{~N} \\
165.9 \mathrm{E}\end{array}$ \\
\hline $\begin{array}{l}\text { Uniform } \\
\text { drape, } \\
100 \mathrm{~m} \\
\text { thickness }\end{array}$ & 3.0 & $\begin{array}{r}20.8 \mathrm{~N} \\
214.8 \mathrm{E}\end{array}$ & $\begin{array}{r}89.9 \mathrm{~N} \\
169.4 \mathrm{E}\end{array}$ & $\begin{array}{r}89.9 \mathrm{~N} \\
181.2 \mathrm{E}\end{array}$ & $\begin{array}{r}89.9 \mathrm{~N} \\
177.2 \mathrm{E}\end{array}$ & $\begin{array}{r}88.0 \mathrm{~N} \\
159.4 \mathrm{E}\end{array}$ & $\begin{array}{r}86.3 \mathrm{~N} \\
160.7 \mathrm{E}\end{array}$ & $\begin{array}{r}85.4 \mathrm{~N} \\
160.4 \mathrm{E}\end{array}$ \\
\hline $\begin{array}{l}\text { Uniform } \\
\text { drape, } \\
1000 \mathrm{~m} \\
\text { thickness }\end{array}$ & 29.6 & $\begin{array}{r}20.8 \mathrm{~N} \\
214.8 \mathrm{E}\end{array}$ & $\begin{array}{r}89.4 \mathrm{~N} \\
175.6 \mathrm{E}\end{array}$ & $\begin{array}{r}88.9 \mathrm{~N} \\
175.0 \mathrm{E}\end{array}$ & $\begin{array}{r}88.6 \mathrm{~N} \\
175.2 \mathrm{E}\end{array}$ & $\begin{array}{r}72.5 \mathrm{~N} \\
162.1 \mathrm{E}\end{array}$ & $\begin{array}{r}61.0 \mathrm{~N} \\
164.0 \mathrm{E}\end{array}$ & $\begin{array}{r}56.7 \mathrm{~N} \\
165.0 \mathrm{E}\end{array}$ \\
\hline \multicolumn{3}{|c|}{ b) Each province, 'large' load } & \multicolumn{3}{|c|}{ Tharsis formed close to equator } & \multicolumn{3}{|c|}{ Tharsis formed far from equator } \\
\hline Load & $\begin{array}{l}\text { Volu } \\
\text { me }(\mathrm{x} \\
10^{\wedge} 6 \\
\mathrm{~km}^{\wedge} 3 \\
)\end{array}$ & $\begin{array}{l}\text { Center of } \\
\text { volume }\end{array}$ & $\begin{array}{l}\mathrm{Te}= \\
100 \mathrm{~km}\end{array}$ & $\begin{array}{l}\mathrm{Te}= \\
200 \mathrm{~km}\end{array}$ & $\begin{array}{l}\mathrm{Te}= \\
300 \mathrm{~km} \mathrm{(a)}\end{array}$ & $\begin{array}{l}\mathrm{Te}= \\
100 \mathrm{~km}(\mathrm{~b})\end{array}$ & $\begin{array}{l}\mathrm{Te}= \\
200 \mathrm{~km}(\mathrm{c})\end{array}$ & $\begin{array}{l}\mathrm{Te}=300 \mathrm{~km} \\
(\mathrm{~d})\end{array}$ \\
\hline $\begin{array}{l}\text { Elysium } \\
\text { province }\end{array}$ & 6.6 & $\begin{array}{r}22.3 \mathrm{~N} \\
152.5 \mathrm{E}\end{array}$ & $\begin{array}{r}89.6 \mathrm{~N} \\
154.8 \mathrm{E}\end{array}$ & $\begin{array}{r}89.3 \mathrm{~N} \\
156.1 \mathrm{E}\end{array}$ & $\begin{array}{r}89.1 \mathrm{~N} \\
156.4 \mathrm{E}\end{array}$ & $\begin{array}{r}76.0 \mathrm{~N} \\
160.1 \mathrm{E}\end{array}$ & $\begin{array}{r}64.8 \mathrm{~N} \\
161.2 \mathrm{E}\end{array}$ & $\begin{array}{r}59.3 \mathrm{~N} \\
162.0 \mathrm{E}\end{array}$ \\
\hline $\begin{array}{l}\text { Medusae } \\
\text { Fossae } \\
\text { province }\end{array}$ & 2.2 & $\begin{array}{r}1.4 \mathrm{~S} \\
201.1 \mathrm{E}\end{array}$ & $\begin{array}{r}90.0 \mathrm{~N} \\
335.4 \mathrm{E}\end{array}$ & $\begin{array}{r}90.0 \mathrm{~N} \\
305.5 \mathrm{E}\end{array}$ & $\begin{array}{r}90.0 \mathrm{~N} \\
305.5 \mathrm{E}\end{array}$ & $\begin{array}{r}89.4 \mathrm{~N} \\
335.4 \mathrm{E}\end{array}$ & $\begin{array}{r}89.4 \mathrm{~N} \\
335.4 \mathrm{E}\end{array}$ & $\begin{array}{r}89.4 \mathrm{~N} \\
335.4 \mathrm{E}\end{array}$ \\
\hline $\begin{array}{l}\text { Young } \\
\text { flood lavas }\end{array}$ & 4.1 & $\begin{array}{r}33.1 \mathrm{~N} \\
187.1 \mathrm{E}\end{array}$ & $\begin{array}{r}89.8 \mathrm{~N} \\
174.3 \mathrm{E}\end{array}$ & $\begin{array}{r}89.7 \mathrm{~N} \\
167.3 \mathrm{E}\end{array}$ & $\begin{array}{r}89.6 \mathrm{~N} \\
169.8 \mathrm{E}\end{array}$ & $\begin{array}{r}84.6 \mathrm{~N} \\
160.3 \mathrm{E}\end{array}$ & $\begin{array}{r}80.3 \mathrm{~N} \\
160.2 \mathrm{E}\end{array}$ & $\begin{array}{r}77.2 \mathrm{~N} \\
160.8 \mathrm{E}\end{array}$ \\
\hline $\begin{array}{l}\text { Olympus } \\
\text { province }\end{array}$ & 6.1 & $\begin{array}{r}19.4 \mathrm{~N} \\
224.9 \mathrm{E}\end{array}$ & $\begin{array}{r}89.8 \mathrm{~N} \\
198.5 \mathrm{E}\end{array}$ & $\begin{array}{r}89.7 \mathrm{~N} \\
197.2 \mathrm{E}\end{array}$ & $\begin{array}{r}89.6 \mathrm{~N} \\
196.1 \mathrm{E}\end{array}$ & $\begin{array}{r}85.6 \mathrm{~N} \\
162.9 \mathrm{E}\end{array}$ & $\begin{array}{r}81.8 \mathrm{~N} \\
163.4 \mathrm{E}\end{array}$ & $\begin{array}{r}80.4 \mathrm{~N} \\
163.6 \mathrm{E}\end{array}$ \\
\hline $\begin{array}{l}\text { Tharsis } \\
\text { Montes } \\
\text { province }\end{array}$ & 10.0 & $\begin{array}{r}3.5 \mathrm{~N} \\
248.5 \mathrm{E}\end{array}$ & $\begin{array}{r}89.9 \mathrm{~N} \\
304.4 \mathrm{E}\end{array}$ & $\begin{array}{r}89.9 \mathrm{~N} \\
304.5 \mathrm{E}\end{array}$ & $\begin{array}{r}89.8 \mathrm{~N} \\
309.4 \mathrm{E}\end{array}$ & $\begin{array}{r}87.7 \mathrm{~N} \\
335.0 \mathrm{E}\end{array}$ & $\begin{array}{r}86.0 \mathrm{~N} \\
334.7 \mathrm{E}\end{array}$ & $\begin{array}{r}85.2 \mathrm{~N} \\
335.2 \mathrm{E}\end{array}$ \\
\hline $\begin{array}{l}\text { Alba } \\
\text { province }\end{array}$ & 4.6 & $\begin{array}{r}41.3 \mathrm{~N} \\
249.0 \mathrm{E}\end{array}$ & $\begin{array}{r}89.9 \mathrm{~N} \\
255.2 \mathrm{E}\end{array}$ & $\begin{array}{r}89.8 \mathrm{~N} \\
252.5 \mathrm{E}\end{array}$ & $\begin{array}{r}89.7 \mathrm{~N} \\
251.7 \mathrm{E}\end{array}$ & $\begin{array}{r}89.3 \mathrm{~N} \\
303.0 \mathrm{E}\end{array}$ & $\begin{array}{r}89.1 \mathrm{~N} \\
287.1 \mathrm{E}\end{array}$ & $\begin{array}{r}89.0 \mathrm{~N} \\
280.0 \mathrm{E}\end{array}$ \\
\hline Syria & 1.9 & $15.9 \mathrm{~S}$ & $90.0 \mathrm{~N}$ & $89.9 \mathrm{~N}$ & $89.9 \mathrm{~N}$ & $88.8 \mathrm{~N}$ & $87.9 \mathrm{~N}$ & $87.9 \mathrm{~N}$ \\
\hline
\end{tabular}




\begin{tabular}{|c|c|c|c|c|}
\hline $\begin{array}{l}\text { Crater- } \\
\text { retention age }\end{array}$ & $\begin{array}{l}\text { Polar } \\
\text { material }\end{array}$ & $\begin{array}{l}\text { Mask (younger } \\
\text { materials) }\end{array}$ & Best fit pole location & $\begin{array}{l}\text { (Relative) Confidence that } \\
\text { paleopole is due to TPW? }\end{array}$ \\
\hline \multicolumn{5}{|l|}{$\begin{array}{l}\text { Northern } \\
\text { hemisphere }\end{array}$} \\
\hline \multicolumn{5}{|l|}{$\begin{array}{l}\text { Without ice } \\
\text { outliers }\end{array}$} \\
\hline $\begin{array}{l}\text { 1. Late } \\
\text { Amazonian }\end{array}$ & PB & - & $87.9 \mathrm{~N} 1.4 \mathrm{E}$ & Low to Moderate \\
\hline $\begin{array}{l}\text { 2. Late } \\
\text { Amazonian }\end{array}$ & OD & PB & $87.6 \mathrm{~N} 181.2 \mathrm{E}$ & Moderate \\
\hline $\begin{array}{l}\text { 3. Early } \\
\text { Amazonian }\end{array}$ & $\mathrm{SC}$ & $\mathrm{PB}, \mathrm{OD}$ & $85.0 \mathrm{~N} 206.8 \mathrm{E}$ & Low \\
\hline $\begin{array}{l}\text { 4. Early } \\
\text { Amazonian }\end{array}$ & $\mathrm{SC}, \mathrm{ST}$ & $\mathrm{PB}, \mathrm{OD}$ & $81.3 \mathrm{~N} 198.6 \mathrm{E}$ & Very Low to Low \\
\hline \multicolumn{5}{|l|}{$\begin{array}{l}\text { With ice } \\
\text { outliers }\end{array}$} \\
\hline $\begin{array}{l}\text { Late } \\
\text { Amazonian? }\end{array}$ & IO & $\mathrm{PB}, \mathrm{OD}$ & $84.6 \mathrm{~N} 160.9 \mathrm{E}$ & \multirow{3}{*}{$\begin{array}{l}\text { Ice outliers overlie SC and } \\
\text { ST, but age relative to PB } \\
\text { is uncertain }\end{array}$} \\
\hline $\begin{array}{l}\text { Early } \\
\text { Amazonian? }\end{array}$ & IO, SC & $\mathrm{PB}, \mathrm{OD}$ & $83.7 \mathrm{~N} 185.5 \mathrm{E}$ & \\
\hline $\begin{array}{l}\text { Early } \\
\text { Amazonian? }\end{array}$ & IO, SC, ST & $\mathrm{PB}, \mathrm{OD}$ & $81.3 \mathrm{~N} 189.7 \mathrm{E}$ & \\
\hline \multicolumn{5}{|l|}{$\begin{array}{l}\begin{array}{l}\text { Southern } \\
\text { hemisphere }\end{array} \\
\end{array}$} \\
\hline $\begin{array}{l}\text { 5. Upper } \\
\text { Amazonian }\end{array}$ & SRC & - & 87.3S 315E & n.a. $($ see $\S 1)$ \\
\hline $\begin{array}{l}\text { 6. (?Middle) } \\
\text { Amazonian }\end{array}$ & SPLD & - & $84.3 \mathrm{~S} 162.7 \mathrm{E}$ & Moderate \\
\hline $\begin{array}{l}\text { 7. Late } \\
\text { Hesperian }\end{array}$ & DAF & SPLD & $\begin{array}{l}82.1 \mathrm{~S} 335.9 \mathrm{E} \text { (variable cap } \\
\text { radius) } \\
\begin{array}{l}81.3 S \\
\text { radius) }\end{array}\end{array}$ & High \\
\hline
\end{tabular}




\begin{tabular}{|c|c|c|c|c|c|}
\hline \multirow[t]{2}{*}{ Unit desig. } & \multirow[t]{2}{*}{ Description } & \multicolumn{3}{|c|}{ Unit thickness or truncation elevation (m) } & \multirow[t]{2}{*}{ Notes } \\
\hline & & 'Small' & 'Medium' & 'Large' & \\
\hline \multicolumn{6}{|c|}{ Elysium Province } \\
\hline Hhet & $\begin{array}{l}\text { Hecates } \\
\text { Tholus Fm. }\end{array}$ & $-3000(\mathrm{~T})$ & $-3000(\mathrm{~T})$ & $-3500(\mathrm{~T})$ & \multirow{4}{*}{$\begin{array}{l}\text { Qualitative backstripping } \\
\text { following Tanaka et al. } \\
\text { (1992) }\end{array}$} \\
\hline Ael1 & $\begin{array}{l}\text { Elysium Fm., } \\
\text { member } 1\end{array}$ & 500 & $1000(\mathrm{~T})$ & $-3500(\mathrm{~T})$ & \\
\hline Ael2 & $\begin{array}{l}\text { Elysium Fm., } \\
\text { member } 2\end{array}$ & $2500(\mathrm{~T})$ & $2500(\mathrm{~T})$ & $-3500(\mathrm{~T})$ & \\
\hline AHat & $\begin{array}{l}\text { Albor Tholus } \\
\text { Fm. }\end{array}$ & $-1000(\mathrm{~T})$ & $-1000(\mathrm{~T})$ & $-3500(\mathrm{~T})$ & \\
\hline \multicolumn{6}{|c|}{ Medusae Fossae Formation } \\
\hline \multirow{4}{*}{$\begin{array}{l}\text { Combined } \\
\text { lower, middle } \\
\text { and upper } \\
\text { members of } \\
\text { Fm. }\end{array}$} & W lobes & 500 & $-2700(\mathrm{~T})$ & $-2700(\mathrm{~T})$ & \multirow{4}{*}{$\begin{array}{l}\text { Largely following Bradley } \\
\text { et al. (2002). }\end{array}$} \\
\hline & C lobes & 500 & $-2400(\mathrm{~T})$ & $-2800(\mathrm{~T})$ & \\
\hline & E lobes & 500 & $-2000(\mathrm{~T})$ & $-3000(\mathrm{~T})$ & \\
\hline & Far E lobe & 500 & $+500(\mathrm{~T})$ & $-500(\mathrm{~T})$ & \\
\hline \multicolumn{6}{|c|}{ Young flood lavas } \\
\hline Ael3-4 & $\begin{array}{l}\text { Elysium Fm., } \\
\text { members 3-4 }\end{array}$ & 100 & 200 & 500 & \multirow{2}{*}{$\begin{array}{l}\text { 'Small' values from } \\
\text { SHARAD and MARSIS } \\
\text { subsurface contacts }\end{array}$} \\
\hline Achu & $\begin{array}{l}\text { Younger } \\
\text { channel } \\
\text { system } \\
\text { material, } \\
\text { undivided }\end{array}$ & 75 & 300 & 1000 & \\
\hline Aal & $\begin{array}{l}\text { Arcadia Fm., } \\
\text { member } 1\end{array}$ & 150 & 200 & 500 & $\begin{array}{l}\text { Not between }-55 \text { and }+10 \\
\text { deg E }\end{array}$ \\
\hline $\mathrm{Aa} 2$ & $\begin{array}{l}\text { Arcadia Fm., } \\
\text { member } 2\end{array}$ & 50 & 100 & 200 & \multirow{3}{*}{$\begin{array}{l}\text { 'Small' values from } \\
\text { SHARAD and MARSIS } \\
\text { subsurface contacts }\end{array}$} \\
\hline Aa3 & $\begin{array}{l}\text { Arcadia Fm., } \\
\text { member } 3\end{array}$ & 70 & 100 & 500 & \\
\hline Aa4 & $\begin{array}{l}\text { Arcadia Fm., } \\
\text { member } 4\end{array}$ & 30 & 100 & 200 & \\
\hline $\mathrm{Aa} 5$ & $\begin{array}{l}\text { Arcadia Fm., } \\
\text { member } 5\end{array}$ & 30 & 100 & 200 & $\begin{array}{l}\text { Only between }-180 \text { and } \\
-150 \text { deg E }\end{array}$ \\
\hline Achp & Younger & 30 & 30 & 100 & 'Small' value from \\
\hline
\end{tabular}




\begin{tabular}{|c|c|c|c|c|c|}
\hline & $\begin{array}{l}\text { flood-plain } \\
\text { material }\end{array}$ & & & & $\begin{array}{l}\text { SHARAD and MARSIS } \\
\text { subsurface contacts }\end{array}$ \\
\hline \multicolumn{6}{|c|}{ Olympus Mons province } \\
\hline Aoal & $\begin{array}{l}\text { Olympus } \\
\text { Mons Fm., } \\
\text { aureole } \\
\text { member } 1\end{array}$ & 1000 & 1000 & 1000 & \\
\hline Aoa2-Aoa4 & $\begin{array}{l}\text { Olympus } \\
\text { Mons Fm., } \\
\text { aureole } \\
\text { member 2- } \\
\text { member } 4\end{array}$ & 1500 & 1500 & 2200 & \\
\hline Aos & $\begin{array}{l}\text { Olympus } \\
\text { Mons Fm., } \\
\text { shield } \\
\text { member }\end{array}$ & 3000 & $+0(\mathrm{~T})$ & $-2000(\mathrm{~T})$ & \\
\hline Aop & $\begin{array}{l}\text { Olympus } \\
\text { Mons Fm., } \\
\text { plains } \\
\text { member }\end{array}$ & 500 & 1500 & 2500 & \\
\hline As & Slide material & 3000 & $+0(\mathrm{~T})$ & $-2000(\mathrm{~T})$ & $\begin{array}{l}\text { Only between }-128 \mathrm{E} \text { and - } \\
140 \text { E. As Aos }\end{array}$ \\
\hline Ae & $\begin{array}{l}\text { Eolian } \\
\text { deposits }\end{array}$ & 1500 & 1500 & 2200 & $\begin{array}{l}\text { Only between }-130 \text { and } \\
-150 \text { E. As Aoa2-4. }\end{array}$ \\
\hline \multicolumn{6}{|c|}{ Tharsis Montes province } \\
\hline \multirow{4}{*}{$\begin{array}{l}\mathrm{AHt} 3+\mathrm{At} 6+ \\
\mathrm{As}\end{array}$} & Arsia & $+8000(\mathrm{~T})$ & $+6000(\mathrm{~T})$ & $+4000(\mathrm{~T})$ & \\
\hline & Pavonis & $+5000(\mathrm{~T})$ & $+4000(\mathrm{~T})$ & $+2000(\mathrm{~T})$ & \\
\hline & Ascraeus & $+4000(\mathrm{~T})$ & $+2500(\mathrm{~T})$ & $+0(\mathrm{~T})$ & \\
\hline & "marginal" & 100 & 250 & 250 & \\
\hline At5 & $\begin{array}{l}\text { Tharsis } \\
\text { Montes Fm., } \\
\text { member } 5\end{array}$ & 200 & 500 & 500 & \\
\hline At4 (distal) & $\begin{array}{l}\text { Tharsis } \\
\text { Montes Fm., } \\
\text { member } 4\end{array}$ & 100 & 250 & 500 & \\
\hline \multicolumn{6}{|c|}{ Alba Patera province } \\
\hline $\mathrm{Aau}$ & $\begin{array}{l}\text { Alba Patera } \\
\text { Fm., upper } \\
\text { member }\end{array}$ & $+4500(\mathrm{~T})$ & $+2000(\mathrm{~T})$ & $+0(\mathrm{~T})$ & $\begin{array}{l}\text { Late Hesperian apron and } \\
\text { Earliest Amazonian } \\
\text { summit according to }\end{array}$ \\
\hline
\end{tabular}




\begin{tabular}{|c|c|c|c|c|c|}
\hline Aam & $\begin{array}{l}\text { Alba Patera } \\
\text { Fm., middle } \\
\text { member }\end{array}$ & 1000 & $+2000(\mathrm{~T})$ & $-1000(\mathrm{~T})$ & Ivanov and Head (2006) \\
\hline Hal & $\begin{array}{l}\text { Alba Patera } \\
\text { Fm., lower } \\
\text { member }\end{array}$ & 100 & 200 & 500 & \\
\hline \multicolumn{6}{|c|}{ Syria province } \\
\hline Hsl & $\begin{array}{l}\text { Syria Planum } \\
\text { Fm., lower } \\
\text { member }\end{array}$ & 200 & 500 & 1000 & \\
\hline $\mathrm{Hsu}$ & $\begin{array}{l}\text { Syria Planum } \\
\text { Fm., upper } \\
\text { member }\end{array}$ & 200 & 500 & 1800 & \\
\hline \multicolumn{6}{|l|}{ Other } \\
\hline AHcf & $\begin{array}{l}\text { Ceraunius } \\
\text { Fossae } \\
\text { Formation }\end{array}$ & 200 & 450 & 1000 & \\
\hline "Nf" & $\begin{array}{l}\text { Highly- } \\
\text { deformed } \\
\text { terrain } \\
\text { materials }\end{array}$ & 200 & 500 & 2500 & Adjacent to AHcf only \\
\hline Ht1-2 & $\begin{array}{l}\text { Tharsis } \\
\text { Montes Fm., } \\
\text { members 1-2 }\end{array}$ & 100 & 200 & 500 & \\
\hline Apk & $\begin{array}{l}\text { Knobby } \\
\text { plains } \\
\text { material }\end{array}$ & 100 & 200 & 500 & $\begin{array}{l}\text { Only near to Tharsis } \\
\text { Montes }\end{array}$ \\
\hline
\end{tabular}




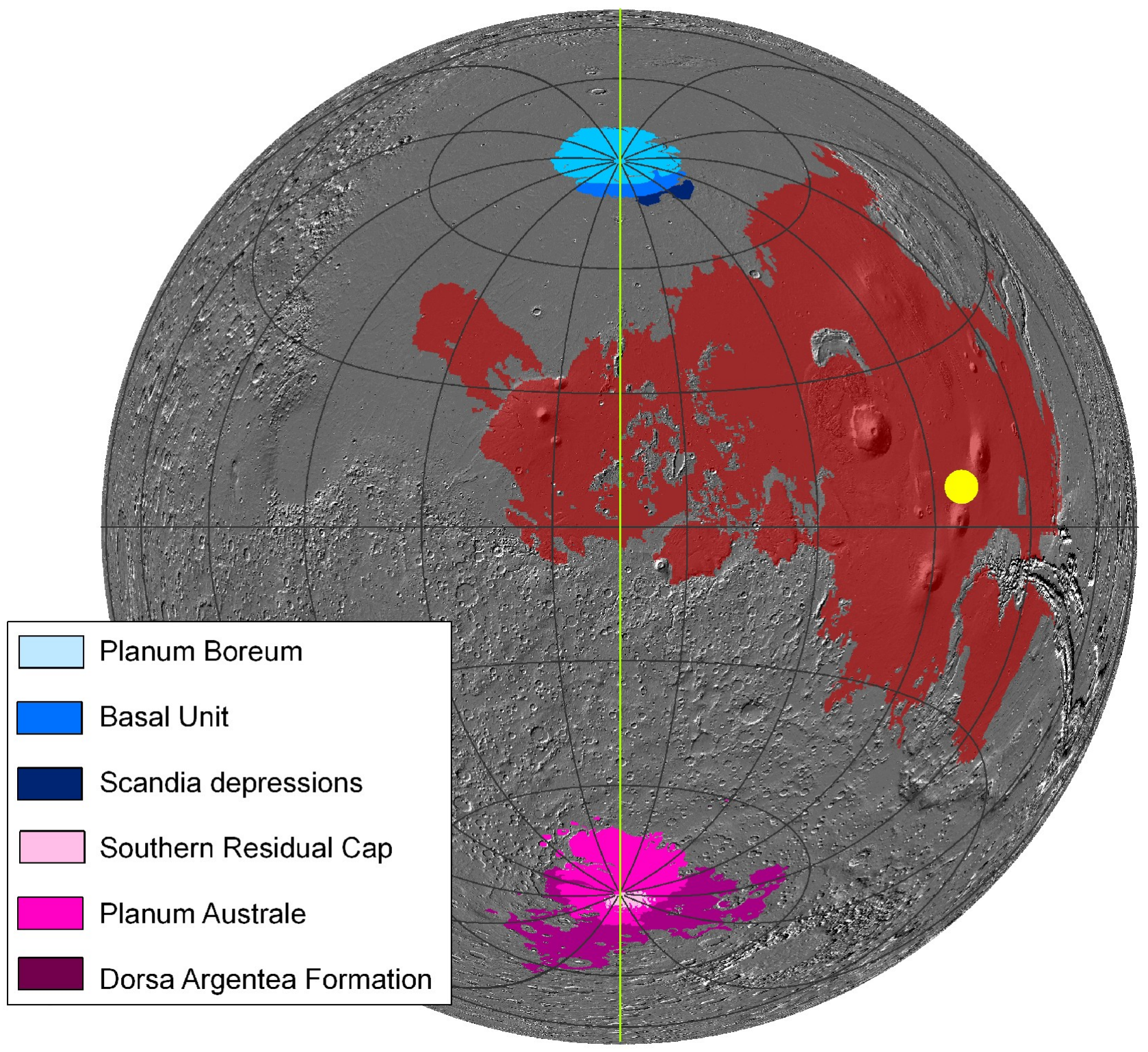




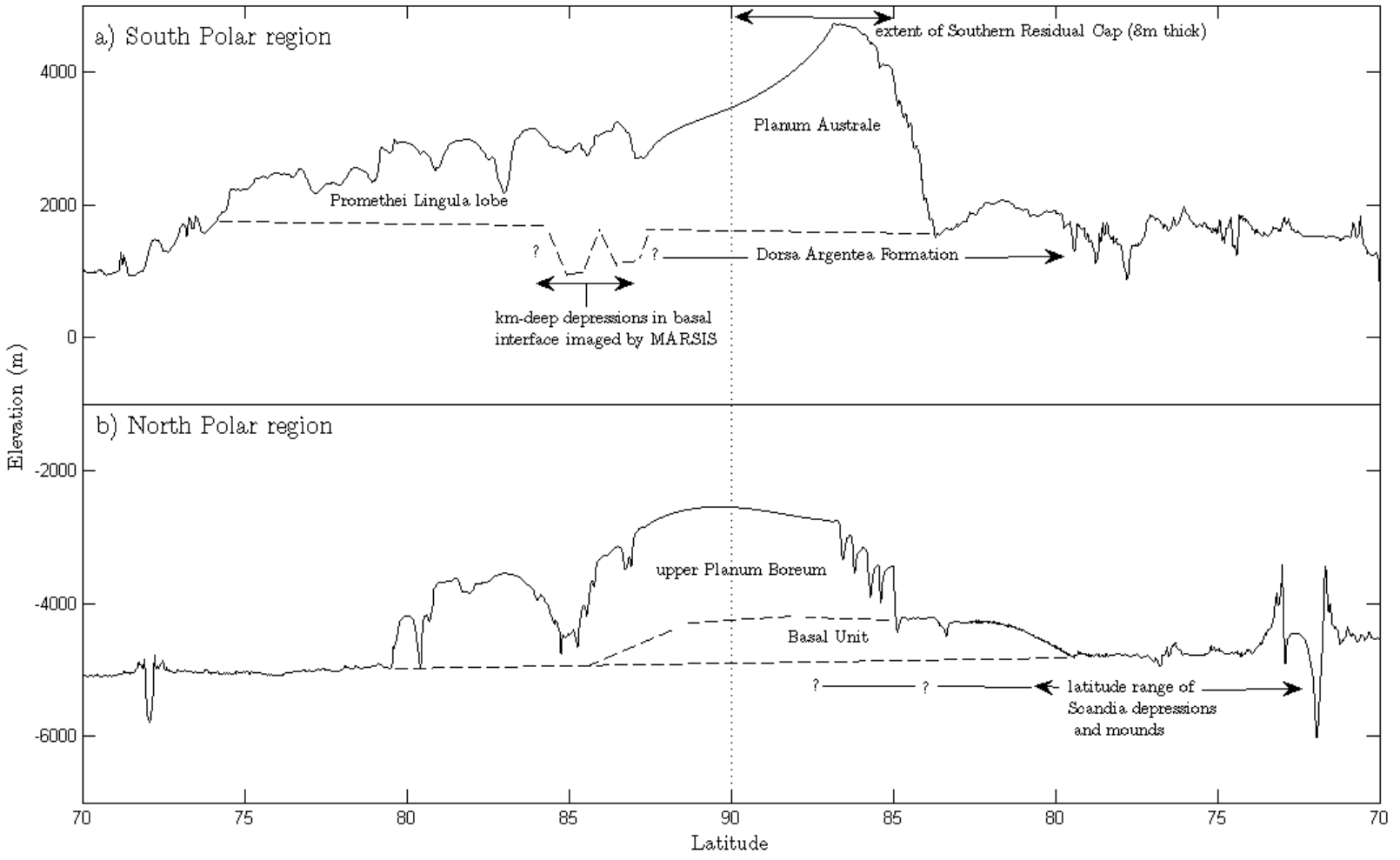



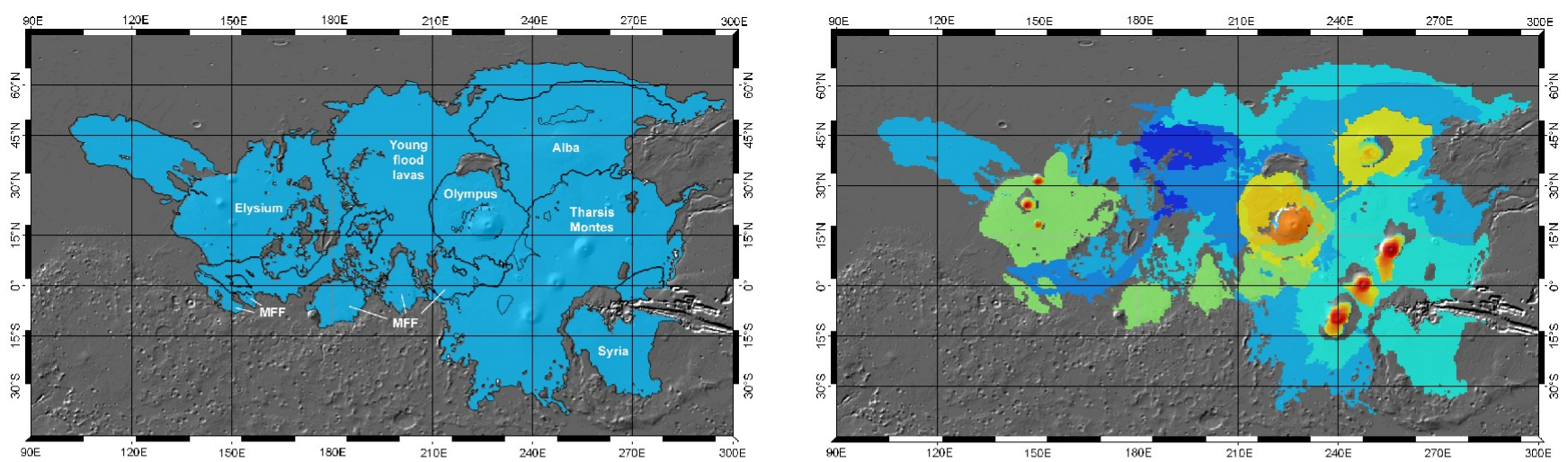

a)

b)

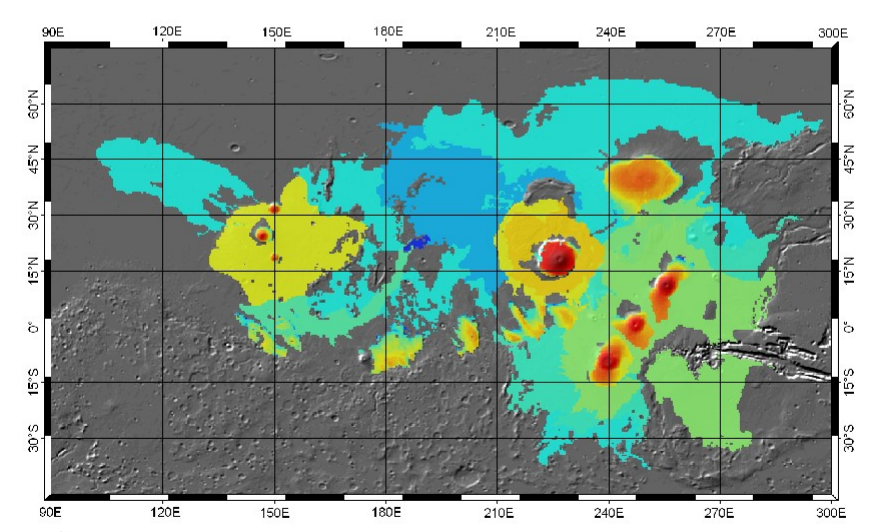

c)

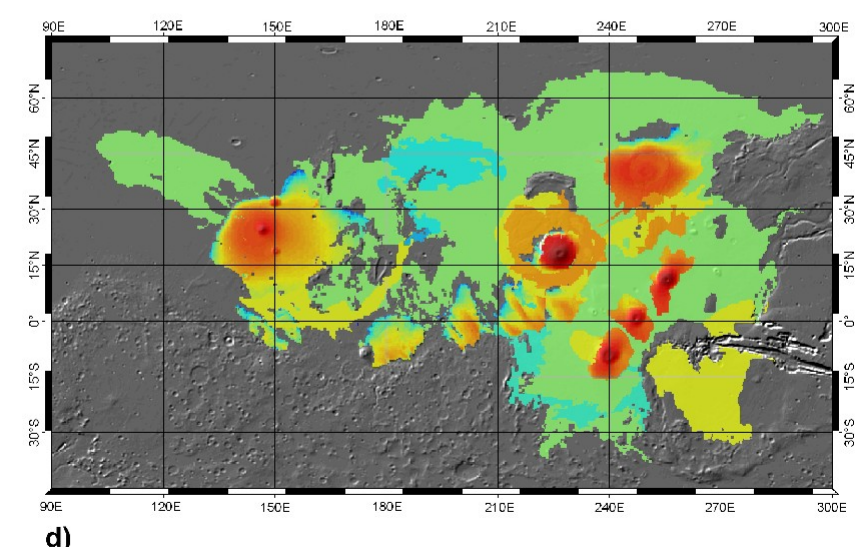

d)

$10 \mathrm{~m}$

$32 \mathrm{~m}$

$100 \mathrm{~m}$

$316 \mathrm{~m} \quad 1000 \mathrm{~m} \quad 3160 \mathrm{~m} \quad 10000 \mathrm{~m}$ 

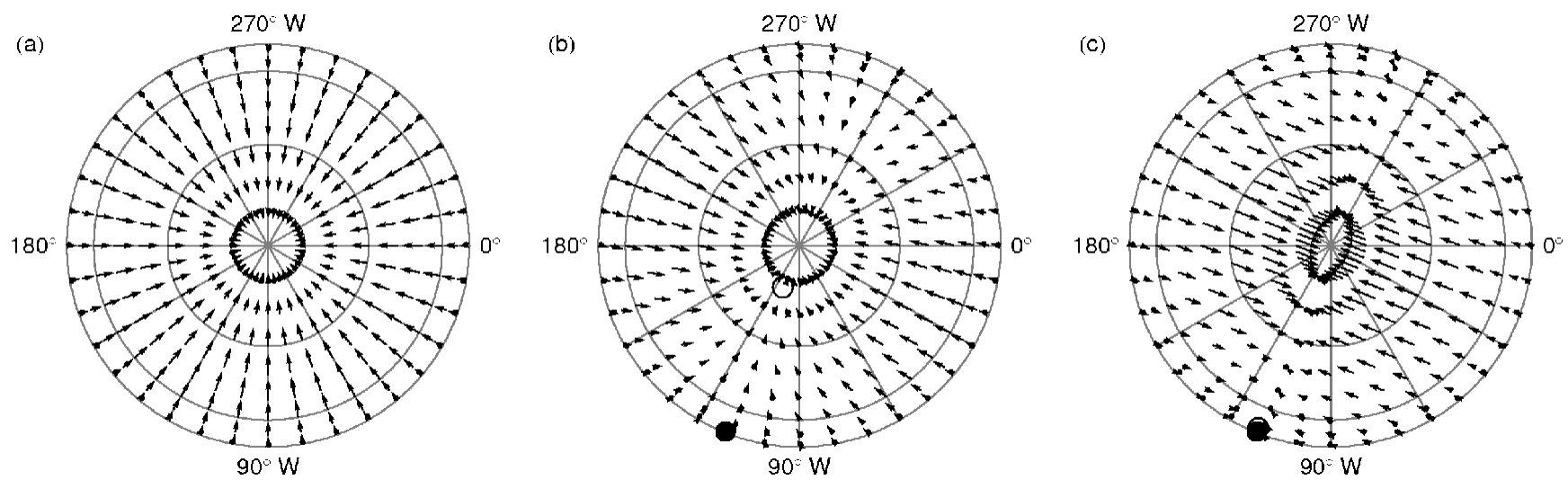


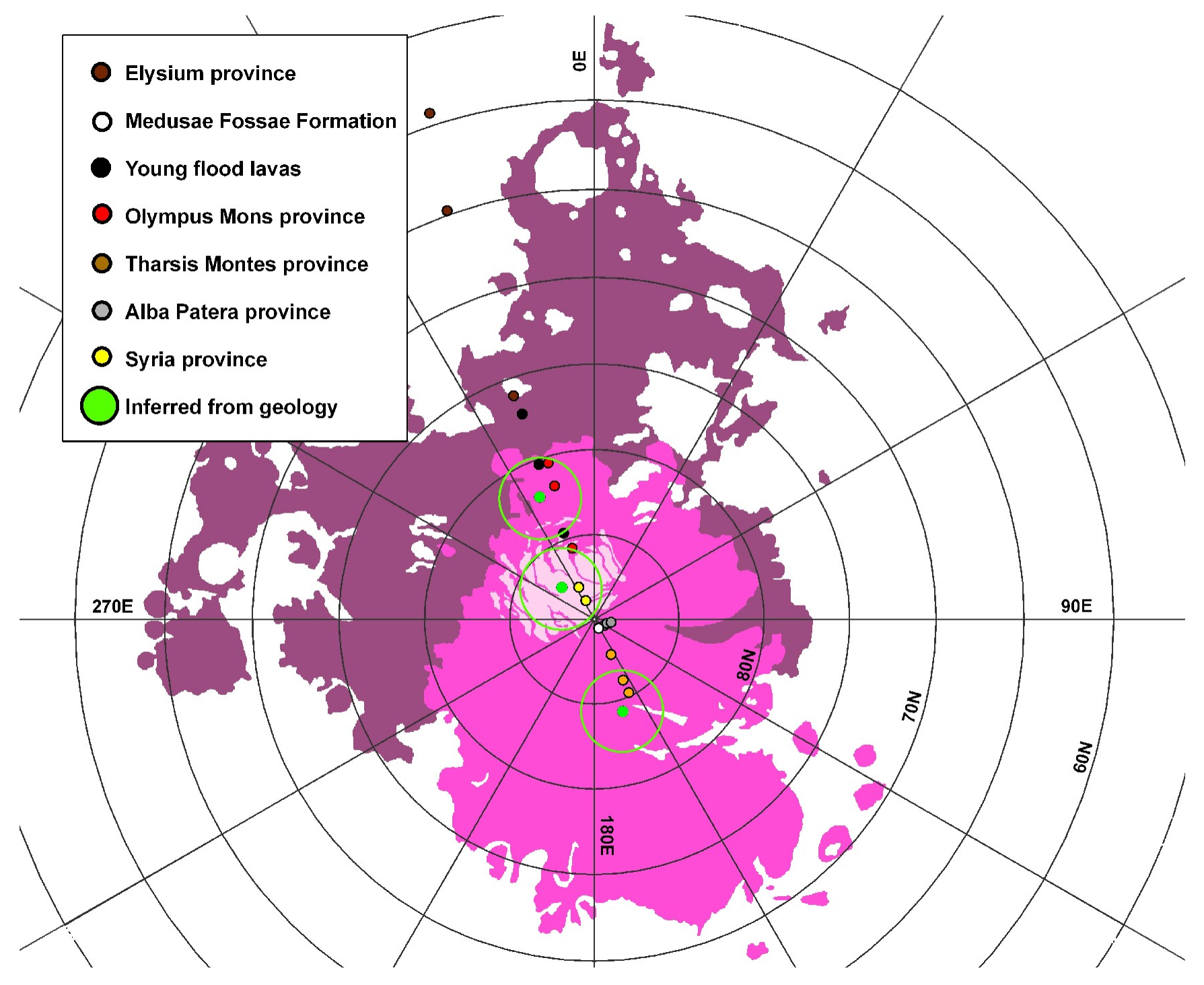




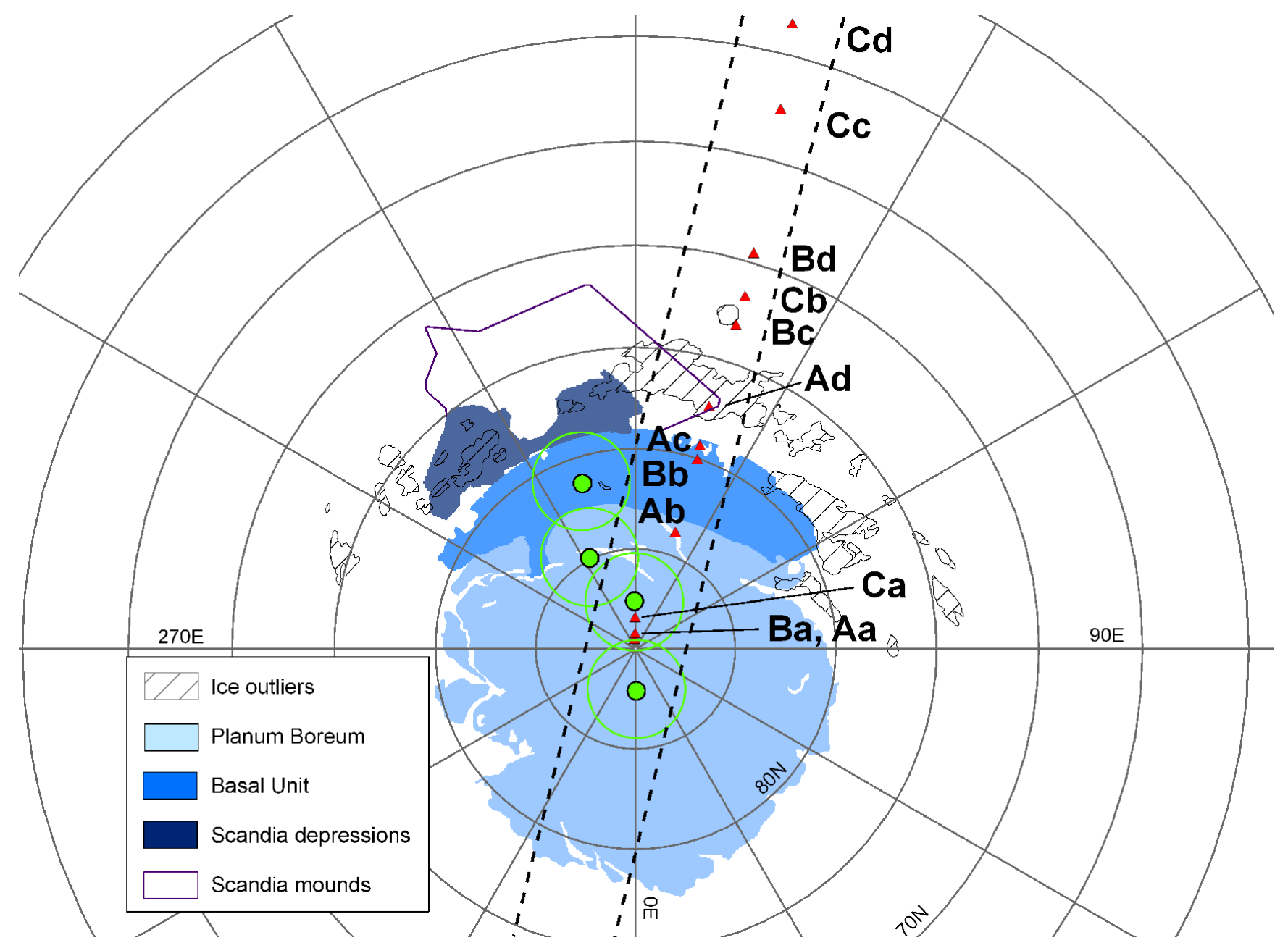




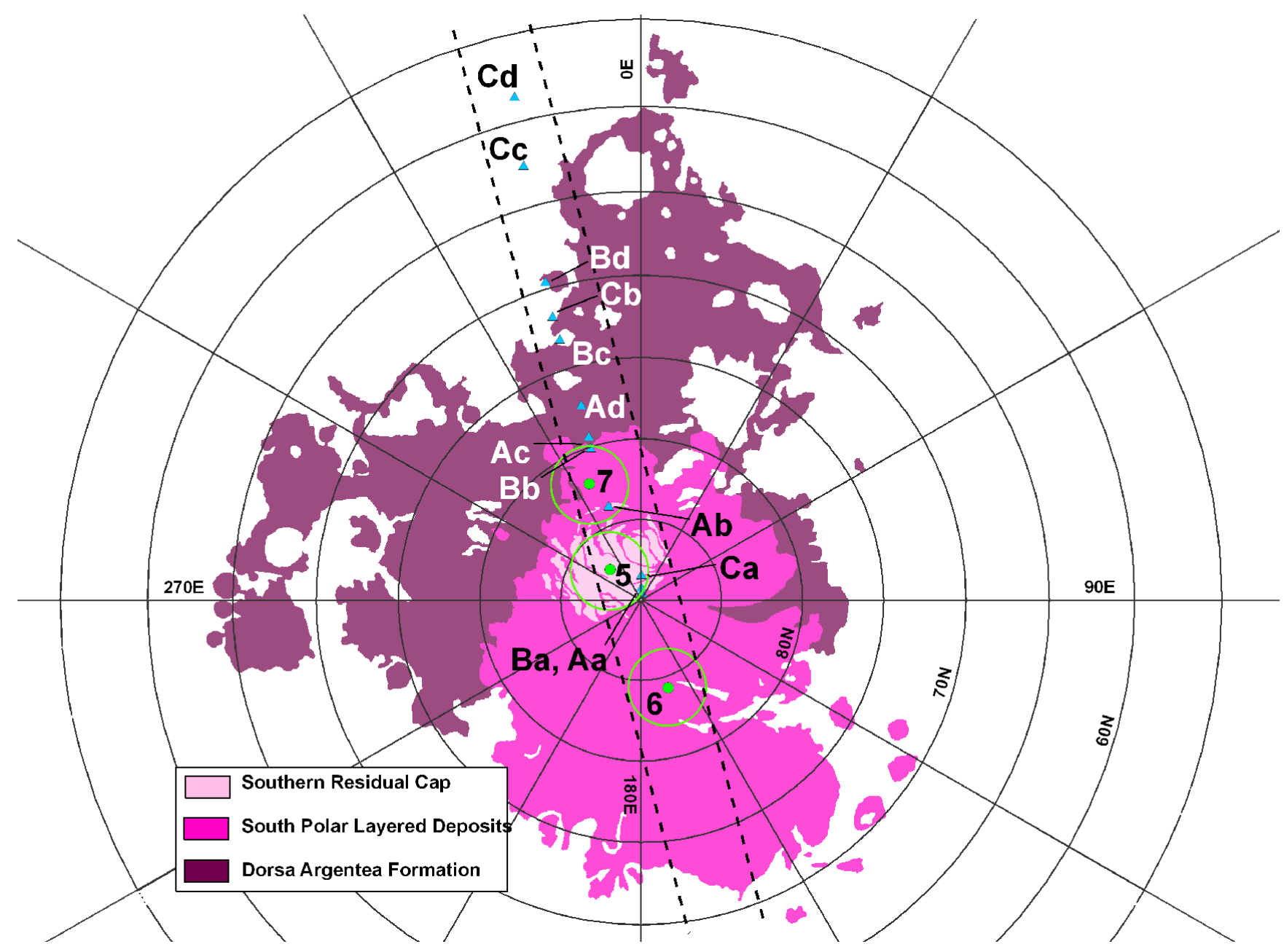


a)

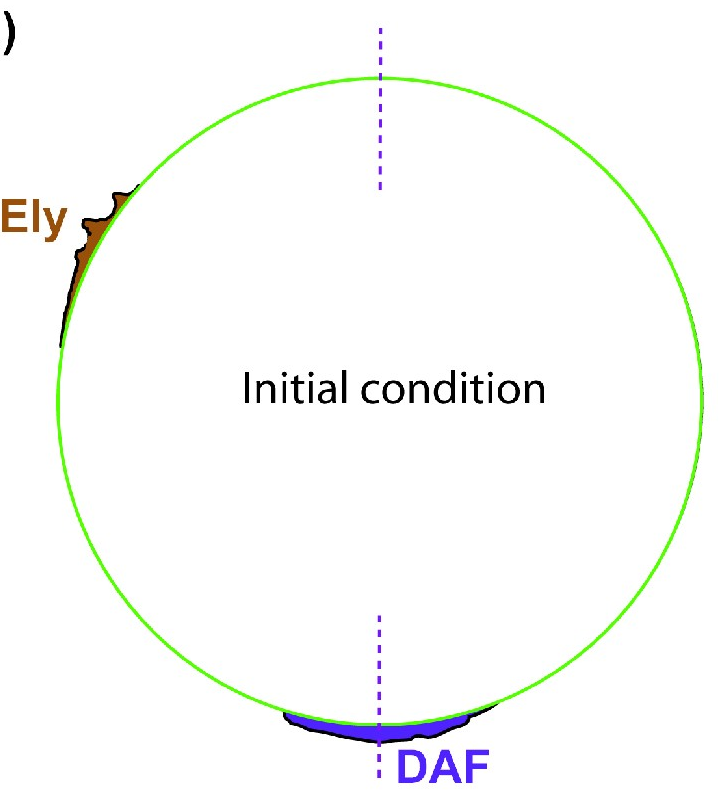

c)

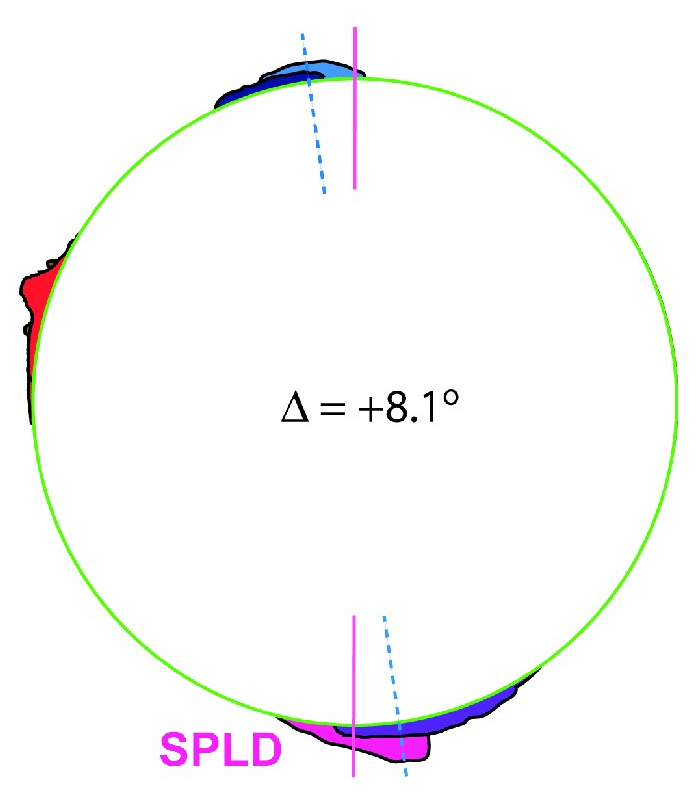

b)
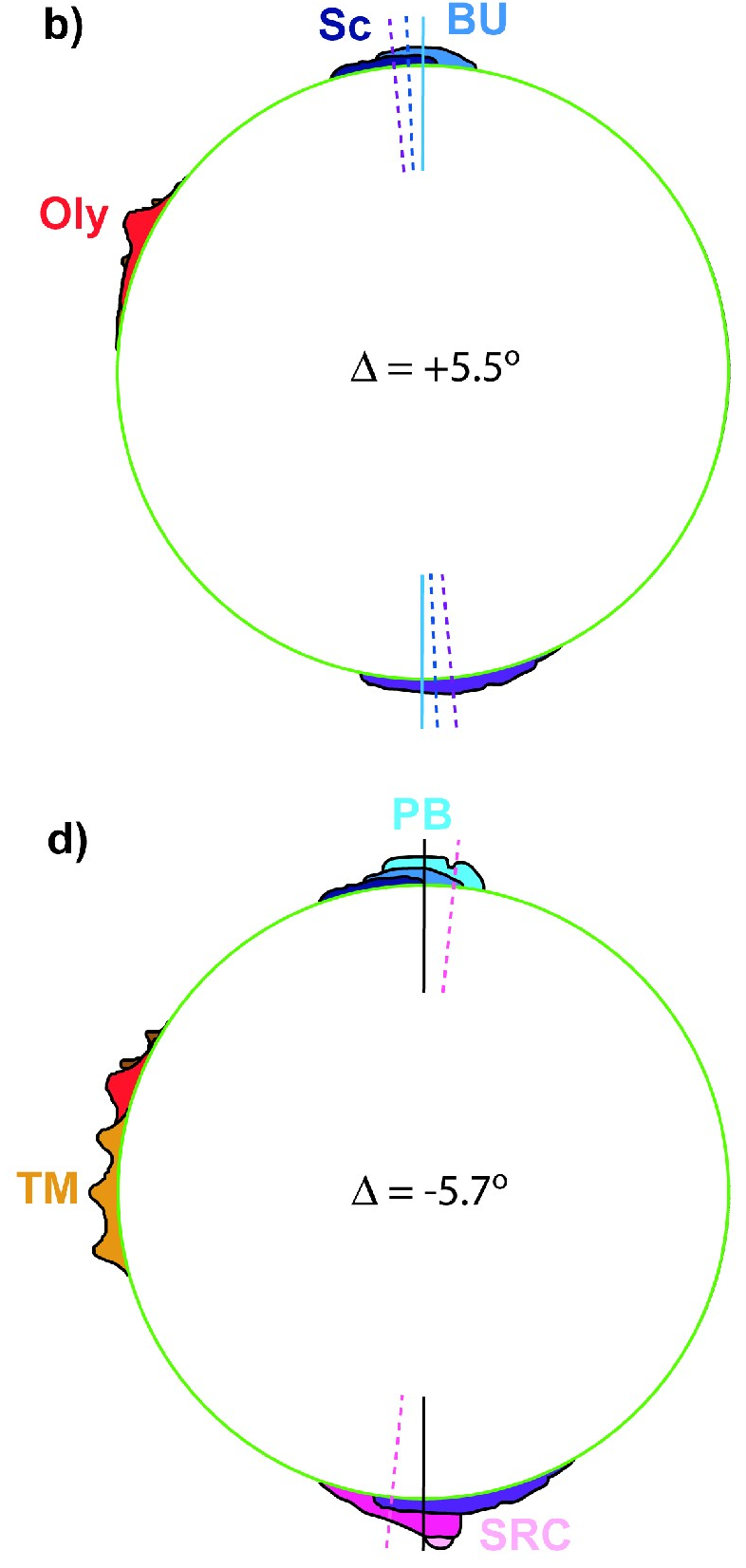


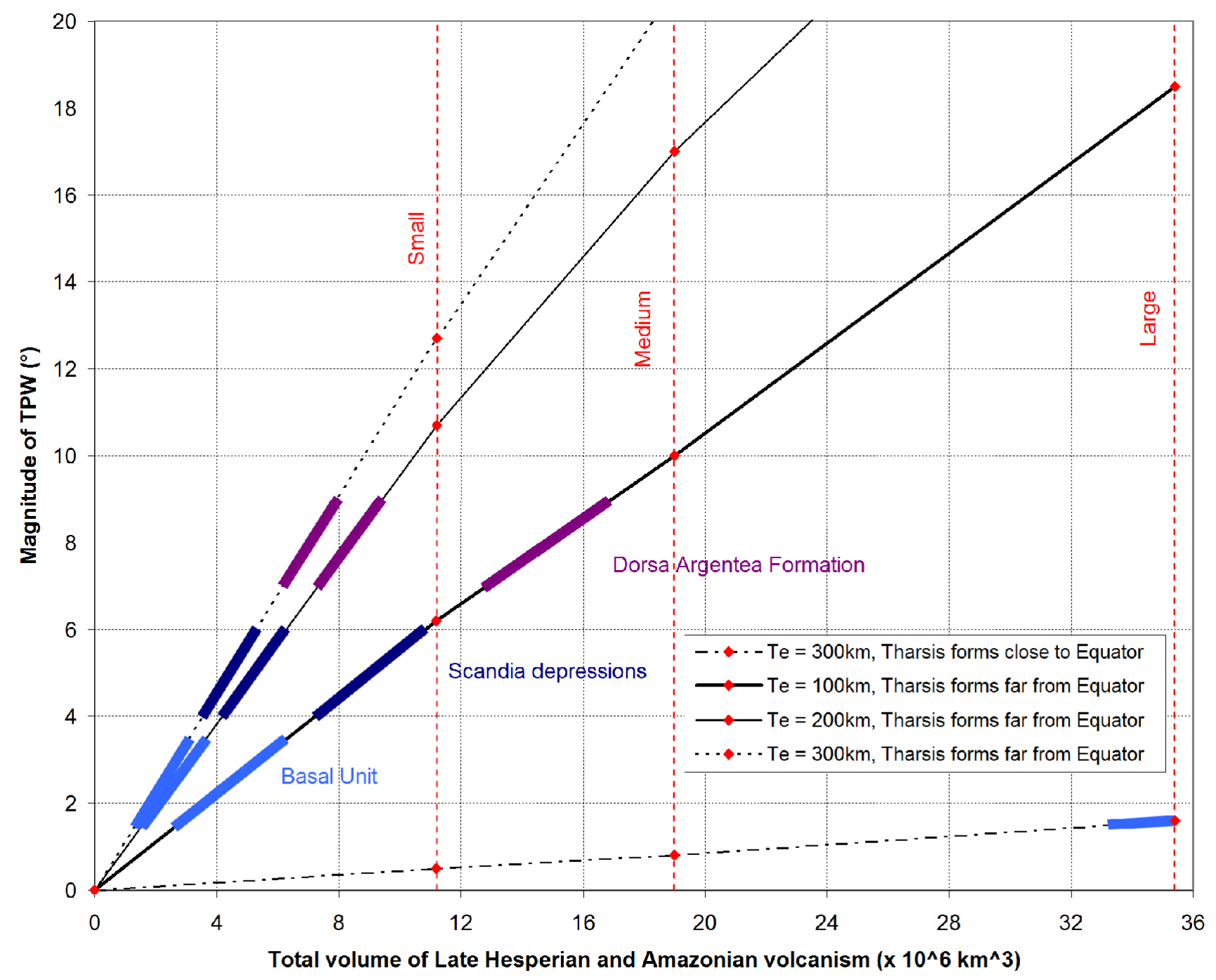

